\title{
Analysis of Antarctic glacigenic sediment provenance through geochemical and petrologic applications
}

\author{
Kathy J. Licht ${ }^{1 *}$ and Sidney R. Hemming ${ }^{2}$ \\ ${ }^{1}$ Department of Earth Sciences, Indiana University Purdue University Indianapolis, Indianapolis, IN USA \\ ${ }^{2}$ Department of Earth and Environmental Sciences, Columbia University and Lamont-Doherty Earth \\ Observatory, Palisades, NY USA
}

*Corresponding Author: klicht@iupui.edu

Keywords

glacial geology; bedrock geology; till; ice-rafted debris; sediment transport; petrography; geochronology; radiogenic isotopes; thermochronology

Highlights

- Antarctica is a patchwork of geological terrains with distinct geologic histories

- Antarctica's ice cover makes its geologic history cryptic

- Antarctica's glacigenic sediment provenance reveals ice sheet and geologic history

- Provenance approaches applied to Antarctica's glacigenic sediments are synthesized

- Multiproxy approaches provide the most robust provenance assessments

This is the author's manuscript of the article published in final edited form as:

Licht, K. J., \& Hemming, S. R. (2017). Analysis of Antarctic glacigenic sediment provenance through geochemical and petrologic applications. Quaternary Science Reviews, 164, 1-24. https://doi.org/10.1016/j.quascirev.2017.03.009 


\begin{abstract}
The number of provenance studies of glacigenic sediments in Antarctica has increased dramatically over the past decade, providing an enhanced understanding of ice sheet history and dynamics, along with the broader geologic history. Such data have been used to assess glacial erosion patterns at the catchment scale, flow path reconstructions over a wide range of scales, and ice sheet fluctuations indicated by iceberg rafted debris in circumantarctic glacial marine sediments. It is notable that even though most of the bedrock of the continent is ice covered and inaccessible, provenance data can provide such valuable information about Antarctic ice and can even be used to infer buried rock types along with their geo- and thermochronologic history. Glacigenic sediments provide a broader array of provenance analysis opportunities than any other sediment type because of their wide range of grain sizes, and in this paper we review methods and examples from all size fractions that have been applied to the Antarctic glacigenic sedimentary record. Interpretations of these records must take careful consideration of the choice of analytical methods, uneven patterns of erosion, and spatial variability in sediment transport and rock types, which all may lead to a preferential identification of different elements of sources in the provenance analyses. Because of this, we advocate a multi-proxy approach and highlight studies that demonstrate the value of selecting complementary provenance methods.
\end{abstract}




\section{Introduction}

The persistence of the Antarctic ice sheet through warm interglacial periods sets it apart from most continental-scale northern hemisphere ice sheets. While Antarctica provides important opportunities to directly study modern ice dynamics and geomorphic processes, we cannot rely as readily on the glacial geomorphology to reconstruct its past configuration as pioneering naturalists Schimper, Charpentier, Agassiz, Chamberlain and others used in the 1800's to begin to understand the history and influence of glacier ice on the landscape. Although tremendous progress has been made in understanding Antarctic ice with multibeam swath bathymetric data that provided paradigm-shifting images of the continental shelf geomorphology (e.g., Shipp et al., 1999), targeted sampling of glacial landforms, comparable to terrestrial glacial studies, has been difficult to achieve. . Glacial geologists working in the Antarctic also lack the 'luxury' of having direct access to the bedrock geology. Bedrock geology influences erosion rates and ice flow (e.g., Jamieson et al., 2010; Golledge et al., 2013), and the lithological and geochemical/geochronological expressions of the geologic history of sediment sources provide important tools for tracing the transport pathways of sediment (e.g., Licht and Palmer, 2013; Pierce et al., 2014;) and for probing erosion rates and thus inferring landform evolution of hidden sources (e.g., Thomson et al., 2013).

On glacial-interglacial timescales, changes in Antarctic ice sheet volume have resulted in eustatic sea level changes causing major changes locally to the geomorphology and deposition on continental shelves around Antarctica, but also, globally as coastlines shifted, altering ocean currents and fluvial gradients. This link to global sea level changes strongly motivates ongoing study of Antarctica ice sheets to inform models that can more reliably estimate the potential for future sea level rise, an area of substantial uncertainty (Church et al., 2013). Many of the first-order questions of Antarctic ice sheet history (i.e., ice sheet extent), particularly for the last glacial maximum (LGM), have been addressed (e.g., RAISED consortium, 2014) and data-driven numerical models have been developed that attempt to optimize model outputs with existing geologic data on ice extent and flow pathways (e.g., Golledge et al., 
2013) (Fig. 1). However, many fundamental questions about ice sheet extent and configuration remain even for the last deglaciation, and there is a particularly sparse record for pre-LGM times. The limited exposure of pre-LGM deposits onshore, and limited access to offshore deposits means that relatively few samples have been analyzed. Thus reconstructions mainly rely on indirect geophysical datasets such as marine seismics and airborne radar. However, physical samples provide information essential to ice sheet reconstructions, including analysis of sediment provenance (origin and transport).

In this review we use the term "sediment provenance" or "provenance analysis" in the most general sense: it is the reconstruction of the origin of sediment, that is the sources and processes on the landscape from which the sediment was derived. Provenance analysis has been widely used in glaciated areas of the northern hemisphere for both academic studies of ice sheet history and applied science such as mineral exploration, but has only begun to be widely used in Antarctica in the past decade. Early work in the Ross Sea by Stetson and Upson (1937), using cores collected during the second Byrd Antarctic Expedition, appears to be the first to analyze till composition and infer its provenance. Their sand petrographic analysis showed spatial variation across the Ross Sea, which they speculated meant there were different source terranes upstream. Since that time, efforts have broadened to include a source-tosink approach that evaluates the provenance of terrestrial tills from inland nunataks and follows their contributions to offshore deposits (Licht and Palmer, 2013). We have learned through this strategy that it is possible to obtain sediment eroded from the entirely ice-covered continental interior by collecting till at the most upstream limits of outlet glaciers before ice crosses through and incorporates sediment eroded from the Transantarctic Mountains (Palmer et al., 2012). A diverse suite of provenance tools and multi proxy approaches, ranging from traditional sand petrography to isotopic and geochronological methods, have been applied to Antarctic provenance questions and will be discussed in the paper.

Glacigenic sediments provide a broader array of sediment provenance analysis opportunities than any other sediment type because of the wide range of grain sizes that characterize them. The provenance tools that have been well tested for sandstones, mudrocks and conglomerates can be applied in 
combination to glacigenic sediments. The challenge (and opportunity) is that the different methodological approaches do not always lead to the same provenance interpretations (e.g., Farmer et al., 2016; Bader et al., in press). Applying a multiproxy approach, and consideration of factors that influence the provenance signal of each, can reveal an incredible amount of detail concerning the history of sources that were eroded by the ice and thus a record of ice sheet history.

In this review paper, we explore the strengths and limitations of provenance methods that have been applied to glacigenic sediments in Antarctica. We begin with a very brief overview of the geology of Antarctica and the origin of glacial sediments as a broad context for understanding the examples that follow. The discussion of methods is divided into particle size groups as the sediment size typically controls which analytical methods are selected for use. We focus on methods that have been most extensively applied to Antarctic glacigenic sediments, including petrography detrital mineral geo- and thermochronology, clay mineralogy, bulk geochemistry and isotopic analyses. The special value of multiproxy approaches is highlighted by two examples that show how records could be misinterpreted or provide an incomplete picture if only a single provenance method is applied. This concept is summarized with simplistic scenarios (Fig. 2) showing how pairing petrographic and geochronologic analysis may allow differentiating geologic terranes. Finally, we have selected examples that show how provenance analysis of Antarctic glacigenic sediments has advanced our knowledge of Antarctica's glacial and geologic history from the continent to the catchment scale and across a broad range of temporal scales.

\section{Background}

2.1. What is the geology of Antarctica that makes this possible?

Many of the topics typically addressed with glacigenic sediment provenance studies, such as ice flowline reconstructions and origin of ice-rafted detritus (IRD), require that the bedrock types and ages have some spatial variability. The scale of that variability and the processes by which sediment is eroded 
and transported affect what provenance signatures are resolvable in the geologic record. Antarctica poses a special challenge because so little bedrock of the continent is exposed and the catchment areas for outlet glaciers can be more than $10^{6} \mathrm{~km}^{2}$. Whereas both the source terranes and glacigenic sediments derived from those deposits can be seen in glaciated areas of the northern hemisphere, Antarctic provenance reconstructions must rely heavily on the glacigenic sediment compositions and textures to make inferences about the geology and geochronology of ice covered areas. This approach is aided by comparison to the limited exposed outcrops and geophysical imaging beneath ice cover to characterize the sediments as tracers of ice flow. As more glacial sediment data become available, a greater understanding of the bedrock geology, as well as the glaciological processes follows. A requirement of the approach is that there is some understanding of the bedrock geology, inevitably making this an iterative process in Antarctica. A review of the geology of Antarctica is beyond the scope of this paper, but we present a broad-brush continental scale overview briefly in the following paragraphs, and in more detail as needed in the examples.

In the broadest sense, East and West Antarctica are divided by the West Antarctic Rift System/Transantarctic Mountains (Fig. 3), and much of West Antarctica lies near or below sea level (Fig. 1) and thus its ice sheets are considered highly vulnerable to global warming and sea level rise (e.g., Hollin, 1962 and many since). The East Antarctic interior completely lacks exposure and descriptions of it range from a stable craton (Tingey, 1991) to a mosaic of mobile belts assembled during the late Proterozoic (Harley et al., 2013). Much of the East Antarctic crystalline bedrock is known or inferred to be pre-Ordovician (with the exception of Jurassic Ferrar dolerite) and is thought to be a patchwork of Archean and Paleoproterozoic terranes that were reworked and sutured together during Grenvillian and Ross/Pan African orogenesis. In contrast, although there is evidence of older heritage in Marie Byrd Land, known West Antarctic plutons are predominantly Devonian and younger, and appear to show less ancient crustal heritage (Tingey, 1991; Siddoway, 2008). The igneous rocks of the Antarctic Peninsula 
reflect a Mesozoic magmatic arc that produced both plutonic and volcanic activity, with peaks in magmatic activity $142 \mathrm{Ma}$ and 125-110 Ma; less extensive volcanism continued throughout much of the Cenozoic (Storey, 2007).

Both the composition and geochronology of sedimentary rocks are important in identifying their signature in Quaternary glacigenic sediments. East Antarctica's sedimentary and metasedimentary rocks can broadly be divided into those deposited pre/syn and post Ross/Pan-African orogeny. During the Neoproterozoic-Cambrian, sediment accumulated in the area that is today the Transantarctic and Ellsworth Mountains. Although these rocks are not very well exposed, they show a transition through a rift-passive margin-convergent margin sequence with shifting composition and $\mathrm{U}-\mathrm{Pb}$ zircon ages (e.g., Goodge et al., 2004; Curtis et al., 2004; Flowerdew et al., 2007). After the Ross/Pan African Orogeny, sediments were deposited on a post-orogenic erosional surface to form the Devonian to Jurassic rocks of the Beacon Supergroup. These are predominantly terrestrial fluvial and glacial deposits derived from both East and West Antarctic basement rocks. These rocks are well exposed and therefore well characterized in the Transantarctic Mountains along the Ross Embayment (Fig. 3), but they also occur in the Weddell Embayment (Barrett, 1991); their subglacial extent is not well known. Interpretations of Beacon sediment provenance were initially derived from paleocurrent indicators, and subsequent work on detrital zircon U$\mathrm{Pb}$ ages in these rocks have confirmed inputs from both East and West Antarctic sources (Elliot and Fanning, 2008; Elsner et al., 2013; Elliot et al., 2014). Beacon-derived zircons appear to constitute a significant fraction of zircons in Quaternary tills from the Transantarctic Mountains (Licht et al., 2014; Welke et al., 2016).

\subsection{Origin of glacigenic sediments}

Glacigenic sediments generated in arid polar environments are largely products of mechanical breakdown of bedrock or remobilization of unlithified deposits in the subglacial environment. Experiments have shown that rock-on-rock abrasion reduces asperities on boulders and cobbles to siltsize particles whereas comminution by crushing typically reduces boulders and cobbles down to gravel 
and then sand size debris (Fig. 4a) (Boulton, 1978; Haldorsen, 1981). The sediment produced by these processes, along with boulder-gravel sized material removed during plucking may be entrained and transported at the ice-bed interface or within the ice as englacial debris (Fig. 4b). Sediment transport distances are also influenced by the subglacial bed properties (e.g., Thorliefson and Kristjansson, 1993) (Fig. 4c). New data suggest that chemical weathering in Antarctic subglacial environments may also be important in geochemical cycles (Wadham et al., 2010) and influence the apparent provenance of the clay size fraction, though this volume of subglacially produced clays may be is small.

The compositional and geochronological information derived from glacigenic sediments and their components can be used to elucidate their provenance, that is the source(s) from which they originated and process(es) that led to their existence. A variety of factors can influence the particle size distribution and the geochemical provenance signature of a particular deposit, including bedrock type and degree of fracture, erosion processes and rates, as well as transport and depositional processes. Different rock types yield fundamentally different mineral populations with different grain size distributions depending on their characteristic mineral sizes and compositions, which may yield a mineral-specific minimum size (terminal grade) via abrasion (Dreimanis and Vagners, 1971). Here we provide a brief overview of the glacial processes that may exert some controls on the provenance signature of Antarctic glacigenic sediments.

\subsubsection{Influence of glacial erosion and transport on provenance studies}

Glacial erosion rates vary spatially in Antarctica and this exerts an important influence on provenance records, as substrates that are preferentially eroded will contribute disproportionately to the basal and englacial sediment load that may be deposited on the continental shelf or in deeper waters. Quantifying glacial erosion rates is generally a challenging problem, and in Antarctica the extensive ice cover reduces access to glacially-eroded bedrock that is used to estimate erosion rates with cosmogenic isotopes (e.g., Fogwill et al., 2004). It is useful to consider relative rates of erosion estimated by ice sheet models (e.g., Jamieson et al., 2010; Golledge et al., 2013). Erosion rates have been estimated following 
the idea that glacial erosion is a function of water at the bed, which causes higher basal ice velocities because sliding is enhanced. Thus, erosion potential typically mimics the ice's basal thermal regime and an absence of water at the bed results in an erosion rate of zero. Although studies have shown that coldbased glaciers can cause erosion (Atkins et al., 2002), rates are not well constrained and this process is not currently reflected in most model simulations (c.f., Jamieson et al., 2010). Variations in bedrock erodibility are also not currently included in widely used models, but sediment cover, which shields the bed from erosion, has been considered (Golledge et al., 2013). Despite imperfect inclusion of processes, glacial erosion models serve as an important first approximation of areas that are likely to contribute greater volumes of sediment to the debris load of an ice mass and thus control the resulting glacigenic sediment deposits.

Results from the modelling of Jamieson et al. (2010) highlight the uneven distribution of erosion under the Antarctic ice sheets (Fig. 5a). Maximum erosion typically occurs in focused regions around the continental perimeter in areas of convergent ice flow. Most of the continental interior and some regions of the coast in both East and West Antarctica experience little to no erosion, so bedrock from these areas will be found in lower abundance in glacigenic sediments than their proportional areas. Jamieson et al. (2010) noted that the model approximation of erosion should be viewed with caution in places where bedrock is covered by sediment, such as the bases of ice streams, which may deform and shield bedrock from erosion. Modeling efforts by Golledge et al. (2013) started from a somewhat different premise that maximum velocity, rather than basal temperature, results in maximum erosion rates. They also incorporated an estimate of sediment transport in areas with deforming beds. The result is a sediment flux map for glacial maxima in Antarctica (Fig. 5b) that has many similarities to the map of erosion rate (Fig. 5a) and further emphasizes the reality that spatial variations in glacial erosional processes will lead to preferential representation of areas of higher erosion in glacigenic sediments. This issue is most relevant for comparing samples derived from a broad spatial area that has variations in ice dynamics, particularly in offshore provenance studies of IRD. 
A sediment's provenance is also impacted by glacial entrainment and transport processes that vary within a catchment area. Debris entrainment may occur through several processes, including shear, but are typically highest where basal water freezes on to the base of the ice sheet (e.g., Hooke et al., 2013). Accordingly, the regions with a warm bed and high erosion rates may also have high entrainment rates if conditions allow refreezing to occur. Spatial variations in bed topography and basal ice temperatures cause complex entrainment patterns. In cases where basal freeze-on occurs, the debris eroded and entrained from a bedrock high may be elevated upward into the ice as a 'plume' of debris (Hooke et al., 2013), resulting in relatively long transport distances (Fig. 4b). Basal freeze-on has been described in both East and West Antarctic ice, and for example, basal debris in concentrations as high as $5-20 \%$ by volume is observed in the lower $14 \mathrm{~m}$ of Kamb Ice Stream (Christoffersen et al., 2010; Bell et al., 2011). Transport distances after entrainment are dependent on bed conditions downstream of the source, such that a cold bed should result in longer transport distances because debris does not melt out, whereas a warm bed may lead to release of the entrained debris and shorten transport distances (Hooke et al., 2013) except where a deformable substrate is present (Fig. 4c).

Rock fragments and detrital minerals may be transported very short distances (meters) or more than a thousand kilometers from their origin, and it is difficult to formulate a universal 'rule' that governs transport distance (Hooke et al., 2013). Studies in the northern hemisphere, where pebble lithology can be traced back to bedrock exposures, show that dispersal distances for pebbles are typically $<50 \mathrm{~km}$ and that the concentration of sediments derived from a particular outcrop decreases exponentially with distance from that source (Clark, 1987). However, there are numerous examples of glacial debris, including diamonds, deposited >1000 km from its source (i.e., Andrews and Sim, 1964; Stewart et al., 1988). During subglacial transport over bedrock, grains have a greater likelihood of experiencing size-reducing comminution than if they are transported englacially or subglacially over a deforming bed (e.g., Tulaczyk et al., 1998). This comminution, along with dilution by new debris, reduces the concentration of a distinctive 'indicator' lithology downstream. In areas where ice flows over a deformable bed and 
comminution is zero or near zero, sediment transport distances may be much longer and follow a different dispersal pattern (Thorleifson and Kristjansson, 1993).

Altogether, entrainment of 'fresh' bedrock debris must occur in places where the bed is not protected by a mantle of glacigenic sediment, and entrainment is maximized where basal water is abundant and ice velocity is highest. Once entrained, transport distances are likely to be greatest where basal conditions transform from a hard bed to a deformable bed or where the entrained material is lofted above the basal zone. The continental shelf around Antarctica's perimeter acts as such a deformable substrate and there is substantial evidence that tills in this setting have been deformed (e.g., Livingstone et al., 2012). Thus after debris emerges from the catchments that stretch toward the continental interior where the debris entrainment initiated, it may be transported relatively long distances across the continental shelves before deposition. Data from the Ross Embayment show that sediment entrained upstream of the narrow East Antarctic outlets becomes mixed with sediment eroded from valley walls of the outlets, and are recognizable components of LGM till on the continental shelf (Farmer and Licht, 2016).

Depositional processes may modify the particle size distribution of glacigenic sediments, which in turn may influence size fractions available for provenance study. Grain-size sorting of glacial debris is least significant for transport via sub- and englacial pathways in the absence of water, providing the largest range of size fractions to analyze. Transport by meltwater, wind, or marine currents will lead to substantial sorting, which will limit the availability of size fractions available for analysis. This may lead to challenges such as in the case of ice-rafted silt and clay, which are typically difficult to readily distinguish from background sedimentation in the marine environment (Ruddiman, 1977). Conversely these sorting effects lead to diagnostic particle size distributions that may be used to infer the transportation processes. 


\section{Description of provenance approaches}

\subsection{Introduction}

Many petrological and geochemical/geochronological methods have been applied to Antarctic sediments. This is somewhat reflective of the exploratory stage of this research, but is largely because the range of grain sizes available, the variable nature of the deposits, and method of collection means that not all approaches can be applied to every sample of glacigenic sediment. The ultimate glacigenic sediment provenance strategy would yield the lithological sources, their geologic histories, and the processes by which they were weathered, eroded, transported and deposited at the site of collection. It is (nearly) impossible to fully achieve this ultimate goal, but by considering the parts that are most important, it is possible to make significant inroads towards the full picture of sediment's heritage. The tools we have are mineralogy/petrography, elemental and isotopic compositions, as well as geochronology, thermochronology and chemical and isotopic compositions of individual detrital minerals.

As reviewed above, the glacigenic depositional process, as well as the method of sample collection, influences the provenance signature that may be obtained from sediment samples. Subglacial sediments typically have the widest range of particle sizes and consequently the most tools have been applied to these materials, whereas there is a more limited range of options for studying ice-rafted debris in the Southern Ocean, distant from the continent, because of the small sample sizes. Additionally, sediment transport processes may selectively move less dense or more hydrodynamic materials a greater distance. The grain size limits of marine sediments are based on what can confidently be identified as icerafted material (e.g., Ruddiman, 1977). The coring process necessarily restricts the sample size and thus the maximum particle sizes and volume of material available for analysis. This particularly impacts the studies that rely on population statistics to draw conclusions from pebble size fractions from thin sediment horizons within cores.

Most provenance tools are applied to a limited range of particle sizes and it is worthwhile to consider the consequences of such choices. Glacigenic sediments that are sand-sized and larger can be 
identified or analyzed individually and can therefore be useful as distinctive individuals (compositions or ages) or as populations that can be analyzed as categorical data. Because of the time required to analyze each individual sample, most datasets are restricted to fewer than a few hundred specimens, or sometimes even fewer than 20. Thus provenance approaches on the sand, pebble and cobble fractions of sediment can produce an immense amount of valuable detail, but consideration of how representative those grains are of the population must be part of any interpretation. In contrast, most methods that analyze the provenance of silt and clay size fractions are applied to bulk samples that integrate (average) the information in a very large number of grains. Because silt is commonly the dominant product of glacial erosion, it may be most representative of the integrated signal of eroded parent material (e.g., Dreimanis and Vagners, 1971). The averaging that comes with measuring bulk fine-grained samples minimizes the challenge of collecting a representative sample. Conversely the data can be difficult to interpret when the potential inputs to the bulk signal are complex and values can be produced by non-unique mixtures. Uniquely identifying sources is a particularly challenging problem when they are covered by glacial ice.

Finally, the fundamental particle size of the individual crystals or grains of source rocks, as well as extent and spacing of rock cleavage will also influence whether that particular rock type can be 'seen' with the method in use. To highlight the influence of rock type on provenance results, we have constructed a simplified diagram showing the typical products that might be expected in the sand and silt/clay fraction relative to common rock types (Fig. 6). Most rock types and their constituent minerals, except particularly friable, fine-grained sedimentary rocks, are likely to be represented in the sand fraction in the simple case of subglacial erosion, transport and deposition. Additionally, tills on crystalline bedrock typically do not contain a lot of clay-sized material because it is not produced in large quantities through glacial comminution, thus the expression of the crystalline bedrock erosion on the provenance of clay-sized materials is very small. Likewise, a reworked (recycled shale) component is common if only the clay fraction is considered (e.g., Passchier et al., 2016). A challenge is that many rock types contain quartz, which can dominate this fraction but have almost ubiquitous potential sources. The remaining 
minerals shown in Figure 6 are detrital minerals from the sand fraction of glacigenic sediment whose age and/or chemistry indicate provenance. Importantly not all rock types contribute the same detrital minerals in the size fractions typically analyzed $(0.063-0.5 \mathrm{~mm})$, influencing the apparent provenance of the sediment (i.e., Moecher and Samson, 2006). Furthermore, sampling and/or preparation differences could lead to biases in the proportions of age populations (e.g., Sircombe and Stern, 2002). Chemical weathering processes preferentially remove easily weathered minerals such as amphibole and biotite, reducing the likelihood of their occurrence in sedimentary rocks. In general it may be expected that different rock types will contribute minerals in different proportions. One can imagine a variety of scenarios where analysis of only one detrital mineral may miss key sources of glacigenic sediments. For example, consider the widespread occurrence of the Beacon Supergroup sedimentary rocks and the associated Ferrar dolerites and related basalts in the Transantarctic Mountains. Analysis of zircons only, would miss or at least strongly underestimate the Ferrar inputs whereas analysis of easily weathered minerals would underestimate the Beacon rock input (Bader et al., in press). In the section on examples of the applications we describe more specific examples from the literature and make the case that using a multi-proxy approach is particularly valuable in Antarctic provenance studies.

In the following sections we describe provenance approaches that have been used, with description grouped by the particle size of the analyzed material.

3.2 Pebbles and cobbles $(4-256 \mathrm{~mm})$

Pebbles and cobbles from glacigenic sediments can provide important geologic information about their sources because of the range of textural, lithologic, geochronologic and geochemical data a rock sample can provide. Two approaches can be used with this type of information. First, emphasis may be placed on individual pebbles/cobbles that can be linked directly back to a mapped bedrock type or even a particular exposure if the characteristics are unique (i.e., Anderson et al., 1991; Denton and Marchant, 2000; Hall and Denton, 2000). Opportunities to apply this approach are uncommon in Antarctica because of the limited exposed bedrock as well as the widespread distribution of many of the known rock units. A 
second approach involves collecting a random sample of sufficient size to create a statistically robust representation of the population (i.e., Talarico and Sandroni, 2009; Talarico et al., 2010; Palmer et al., 2012; Bader et al., in press). That sample must be large enough to capture the variation in the population, including subpopulations of low abundance. Obtaining this type of representative sample can be impossible when utilizing gravity core materials because of the limited diameter and length of the core, if the stratigraphic unit of interest is thin, or if onshore sampling sites are remote and difficult to access.

\subsection{Sand (0.063-2 mm)}

\subsubsection{Introduction}

Provenance analysis on the sand size fraction of glacigenic sediments has evolved dramatically and continues to do so as analytical techniques are improved to measure increasingly smaller samples. Sand is typically produced in subglacial settings by the process of crushing (Haldorsen, 1981), but this process may be minimized in places where a deformable bed is present (Tulaczyk et al., 1998). As with the pebble-size fraction, provenance information can be derived from populations of grains as well as individual sand-size grains. The earliest studies (e.g., Stetson and Upson, 1937), used optical methods for sand petrography and heavy mineral identification, and those methods continue to provide valuable provenance information. Petrographic studies have proven to be valuable for assessing till provenance and ice flow paths and the origin of ice-rafted debris. However, common stable minerals like quartz can be derived from a variety of sources and therefore often have an ambiguous origin. To combat this challenge, geochronology of detrital minerals (i.e., amphibole, apatite, feldspar, mica and zircon) has emerged as a valuable tool to link the ages of individual grains to specific source terrains. As noted above, Antarctica presents a particular challenge because most of the bedrock is covered by ice and some of the exposed terrains are very widely distributed. However, double- and triple-dating the same grain or using other multiproxy approaches provides new strategies to maximize provenance information.

\subsubsection{Petrography}


Optical mineralogy and petrography of the sand fraction have been used to identify spatial and temporal changes in subglacial-nearshore (e.g., Anderson et al., 1991, 1992; Smellie, 2000; Licht et al., 2005; Licht and Palmer, 2013) and ice-rafted (Pudsey et al., 2006; Heroy et al., 2008) sediment provenance. In studies utilizing point counts for data collection, three approaches have been used. The Gazzi-Dickinson method is used to characterize mineral grains in the medium sand and finer fraction (Dickinson, 1970; Ingersoll et al., 1984) whereas the Indiana method involves identifying both mineral and lithic fragments of the very coarse-coarse sand fraction (Suttner, 1974; Suttner et al., 1981). The third alternative approach relies on identifying grains from their surficial characteristics rather than optical properties. With any of these approaches, some distinctive individual grains may be critical for determining provenance, but typically $>300$ grains are identified to characterize the population and permit statistical analysis. In some areas of active volcanism, especially around Ross Island and the Antarctic Peninsula, the volcanic signal can overwhelm the non-volcanic source making it difficult to identify variability in the other sedimen contributors (e.g., Heroy et al., 2008, Talarico et al., 2011).

\subsubsection{Heavy minerals}

The ubiquity of sand-sized quartz and feldspar grains from many sources has led geologists to the study of heavy minerals (minerals with density $>2.85 \mathrm{~g} / \mathrm{cm}^{3}$ ) that may provide a more distinctive provenance signature. Typically the fine to very fine sand fraction is analyzed optically, but X-ray diffraction and SEM-EDAX may be used to provide supplementary data (e.g., Troll et al., 1992; Passchier 2001; Damiani and Giorgetti, 2008). Such methods are used to identify mineral assemblages indicative of particular igneous and metamorphic source terranes and thus they provide key provenance information. Although heavy minerals may be subject to hydraulic sorting in glacifluvial and glacimarine settings, this process likely has minimal impact on subglacial deposits. Interestingly, the earliest recognition that subglacial till provenance may be spatially variable in Ross Sea tills comes from heavy mineral analysis by Stetson and Upson (1937). They reported data from a transect of cores along the Ross Ice Shelf front and found opposing trends in the abundance of pyroxene and amphibole, with more pyroxene closer to 
East Antarctica. Later work on tills in this area and other parts of the Antarctic continental margin has identified distinctive assemblages that were linked to onshore outcrops (i.e., Domack, 1982; Anderson et al., 1984; Hauptvogel and Passchier, 2012). Analysis of heavy mineral assemblages has also been applied to surficial glacimarine sediments in the Weddell Sea where distinct source terranes could be identified (Diekmann and Kuhn, 1999).

\subsubsection{Geochronology and thermochronology of detrital minerals}

Dates on detrital minerals provide important insights into the geological history of their sources. Each mineral isotopic system has a characteristic closure temperature, below which diffusive loss of the daughter becomes negligible (for review see Reiners and Brandon, 2006). To put it not quite accurately, but conceptually, that is the temperature below which the radiogenic clock begins 'ticking'. Figure 7 provides an overview of the approximate closure temperature ranges of commonly applied chronometers. Many mineral high- and medium-temperature chronometers record the time of crystallization because they formed at temperatures below their closure temperature. Low temperature chronometers only preserve ages near the crystallization age in cases of extremely fast cooling (e.g., minerals in volcanic deposits). In the following we provide brief overviews of commonly used detrital mineral chronometers.

\subsubsection{Zircon}

Zircon, $\mathrm{ZrSiO}_{4}$, is an orthosilicate accessory mineral that forms within igneous and hightemperature metamorphic systems. Although a trace constituent, zircon is found in an extremely wide array of rock types, albeit in variable concentrations. It has been widely used in geochronology and provenance studies because its extremely high $\mathrm{U} / \mathrm{Pb}$ ratio allows robust age estimates and because the high degree of stability in a range of high and low temperature environments means it can move through the rock cycle via many pathways with little alteration except rounding (by abrasion or by partial dissolution during weathering or melting) that usually removes tips of the crystal, or by addition of overgrowths. Many tools have been used to characterize zircons, including cathodoluminescence, $\mathrm{U} / \mathrm{Pb}$, fission track and (U-Th)/He dating, Hf-isotopes, elemental concentrations and O isotopes. Many of these 
methods could be used on the same crystal. The near ubiquity of zircon, its ability to retain ancient geological information and the range of geochemical tracers offers researchers multiple ways to assess the provenance of grains, resulting in a proliferation of publication on zircons (c.f., Hanchar and Hoskin, 2003).

The U/Pb system in zircon is a powerful chronometer because of zircon's great stability as well as the very high $\mathrm{U}$ and very low initial $\mathrm{Pb}$ concentrations and the very high closure temperature for diffusion of $\mathrm{Pb}$ (Fig. 7). Two isotopes of $\mathrm{U}$ (238 and 235) decay to two isotopes of $\mathrm{Pb}$ (206 and 207, respectively) and this means that a single $\mathrm{U} / \mathrm{Pb}$ analysis yields three ages (two independent ages). Accordingly, the degree of concordance (how well the independent ages match each other) provides an important means of discerning any disturbance or mixing due to the geologic history of its source. The analytical techniques for in situ measurement of zircons have been widely applied in Antarctica to understand the geologic history of exposed bedrock (e.g., Pankhurst et al., 1998; Goodge and Fanning, 1999; Flowerdew et al., 2007; Elsner et al., 2013) as well as to fingerprint the debris transported by ice emanating from various regions of the continent (e.g., Goodge et al., 2010; Palmer et al., 2012; Licht and Palmer, 2013; Pierce et al., 2014; Licht et al, 2014).

In addition to the $\mathrm{U}-\mathrm{Pb}$ system, thermochronology of detrital zircon using fission track (e.g., Bernet and Garver, 2005) and (U-Th)/He (e.g., Reiners, 2005) dating, can provide information about the subsequent cooling and/or heating histories following crystallization. In simple cases fission tracks in zircons (ZFT) are annealed above a temperature of $\sim 220^{\circ} \mathrm{C}$ while the (U-Th)/He system (ZHe) becomes completely open to diffusion at $\sim 180^{\circ} \mathrm{C}$ (Fig. 7). For normal geothermal gradients between 25 and 35 ${ }^{\circ} \mathrm{C} / \mathrm{km}$, this would equate to when the zircon was last at 6-9 or 5-7 $\mathrm{km}$ respectively. Thus in most cases the ZFT age is expected to be older than the ZHe age, and both are expected to be younger than the U-Pb age. It is important to note that even if the systems are complicated, the combinations still yield extra insights that can help connect sediments to their sources. 
The double- or triple-dating of individual detrital zircon grains provides powerful insight into the geologic history of sediments' sources (e.g., Reiners, 2005; Tochilan et al., 2012; Thomson et al., 2013; Welke et al., 2016). No single grain of sand in glacigenic sediment must be from the same source as any other single grain, but any chronometer or geochemical tracer in a single grain must have experienced the same geological history. Thus obtaining multiple lines of evidence from an individual grain gives significant insight that can be used to evaluate the full spectrum of detrital thermochronometers.

\subsubsection{2. ${ }^{40} \mathrm{Ar} /{ }^{39} \mathrm{Ar}$ in detrital minerals}

Particularly in glacigenic sediments that have been exposed to minimal chemical weathering, the ${ }^{40} \mathrm{Ar} /{ }^{39} \mathrm{Ar}$ ages of dispersed K-bearing minerals such as hornblende, biotite, muscovite and feldspar can provide information on the last major tectonothermal event(s) in the sediments' source area. Collectively these thermochronometers span a closure temperature range of $\sim 550-200^{\circ} \mathrm{C}$ (McDougall and Harrison, 1999; Reiners and Brandon, 2006), and thus overlap the high- and low-temperature thermochronometers (Fig. 7). The ${ }^{40} \mathrm{Ar} /{ }^{39} \mathrm{Ar}$ method has been applied effectively in North Atlantic (e.g., see review by Hemming, 2004) and Antarctic (e.g., Roy et al., 2007; Williams et al., 2010; Pierce et al., 2011, 2014; Cook et al., 2014; Palmer et al., 2012; Welke et al., 2016) glacigenic studies, and in river sediments from rapidly eroding mountain areas (e.g., Hodges et al., 2005).

Hornblende is a common rock-forming mineral that is found in a variety of igneous and highgrade metamorphic rocks. Although potassium is not part of its stoichiometry, it tends to have high enough concentrations that it is practical to measure ${ }^{40} \mathrm{Ar} /{ }^{39} \mathrm{Ar}$ ages on grains that are at least $150 \mu \mathrm{m}$ ( $>250 \mu \mathrm{m}$ is preferred). The closure temperature for diffusion of argon in hornblende depends on the composition (e.g., Dahl, 1996), grain size and cooling rate, but is approximately 500-600 C (Reiners and Brandon, 2006). The high closure temperature means that the clock is only set by crystallization or cooling from very high temperatures (Fig. 7), and thus ages from detrital hornblende grains represent significant tectonothermal events in the source regions. 
Muscovite and biotite are common rock forming minerals that are found in a variety of igneous and metamorphic rocks and have typical closure temperatures between 300 and $400 \mathrm{C}$ (Reiners and Brandon, 2006) (Fig. 7). Muscovite is typically found in very felsic igneous compositions as well as metamorphic rocks of shale protolith, and it is relatively abundant in sandstones and siltstones. Muscovite has been used in a variety of studies to understand exhumation of orogenic belts, and Hodges et al. (2005) present a review of some of the approaches. In Antarctica, only a few studies have included ${ }^{40} \mathrm{Ar} /{ }^{39} \mathrm{Ar}$ in detrital muscovite (e.g., van de Flierdt et al., 2006). We have rarely seen it in our samples, and its apparent occurrence may be biased by sample preparation. Evaluating the ${ }^{40} \mathrm{Ar} /{ }^{39} \mathrm{Ar}$ muscovite potential for provenance in Antarctica would be a good avenue for future research.

Biotite is found in a wide range of igneous and metamorphic rock compositions, but it tends to alter readily from chemical weathering, which renders the ${ }^{40} \mathrm{Ar} /{ }^{39} \mathrm{Ar}$ system meaningless. In our experience only grains that are glassy and black should be selected for biotite measurements, while grains that have altered to a golden color yield near-zero apparent ages (unpublished data from Gilbert Hanson and his students at Stony Brook). Glacially derived sediments have a good chance of not having extensive chemical alteration, and a survey of detrital biotite ${ }^{40} \mathrm{Ar} /{ }^{39} \mathrm{Ar}$ ages compared to detrital hornblende ${ }^{40} \mathrm{Ar} /{ }^{39} \mathrm{Ar}$ ages and detrital zircon U-Pb ages shows good general agreement among the systems, with main populations tending to be (slightly) progressively younger for $\mathrm{U}-\mathrm{Pb}$ zircon, ${ }^{40} \mathrm{Ar} /{ }^{39} \mathrm{Ar}$ hornblende and ${ }^{40} \mathrm{Ar} /{ }^{39} \mathrm{Ar}$ biotite respectively (Pierce et al., 2014). In addition to the simple thermochronological trends for most samples, Pierce et al. (2014) found some cases where biotite reflects an entirely different geologic province than the hornblende, highlighting the value of applying multiple thermochronometers in order to have a better chance of sampling a wider range of geological provinces on the landscape.

\subsubsection{Detrital apatite fission track}

Apatite is a common accessory mineral in a wide range of rock types. The fission track system in apatite is widely used as a thermochronometer (e.g., Gallagher et al., 1998; Zattin et al., 2010, 2014). The temperature above which the fission tracks are annealed in apatite depends on the cooling rate as well as 
the composition of the apatite, but is approximately $100^{\circ} \mathrm{C}$ (Fig. 7), so the fission track age represents approximately the last time the apatite was at 3 to $4 \mathrm{~km}$ depth (for geothermal gradients of 35 to $25^{\circ} \mathrm{C} / \mathrm{km}$ respectively). Apatite does not tend to survive chemical weathering, so is not likely to be derived as detritus from recycled sedimentary rocks, therefore apatite mostly represents first cycle crystalline sources.

The combination of two or three (fission-track and (U-Th)/He or U-Pb and (U-Th)/He, or fissiontrack, $\mathrm{U}-\mathrm{Pb}$ and $(\mathrm{U}-\mathrm{Th}) / \mathrm{He})$ thermochronometers in a single grain of apatite yields great insights into the geological and/or denudation history of the sources of individual grains in a sedimentary sample (e.g., Cox et al., 2010; Tochilin et al., 2012; Zattin et al., 2012; Thomson et al., 2013; Welke et al., 2016). The closure temperature to diffusion of $\mathrm{Pb}$ in apatite depends on the cooling rate as well as composition and grain size, but is approximately $500^{\circ} \mathrm{C}$ (Fig. 7), making it equivalent to the hornblende ${ }^{40} \mathrm{Ar} /{ }^{39} \mathrm{Ar}$ system (e.g., Tochilin et al., 2012). Thomson et al. (2012) have developed a robust laser ICP-MS method for estimating $\mathrm{U}-\mathrm{Pb}$ ages of apatites, although the intermediate- to low- $\mathrm{U} / \mathrm{Pb}$ ratios in apatites can make it challenging to derive precise dates. By sequentially making fission-track, laser ablation $\mathrm{U}-\mathrm{Pb}$ and then (U-Th)/He measurements, it is possible to obtain triple dates that reflect cooling from $\sim 500-600^{\circ} \mathrm{C}$ to $60^{\circ}$ C in simple cases (Fig. 7), or at least elucidate the thermal history within that range of temperatures (e.g., Tochilin et al., 2012; Zattin et al, 2012, Thomson et al., 2013).

3.4. Silt and Clay $(<0.063 \mathrm{~mm})$

\subsubsection{Introduction}

Silt-sized glacigenic particles, along with a lesser amount of clay sized sediment (often collectively called 'fines') are most abundant in subglacial till, but may be preferentially removed from ablation tills by wind or from glacifluvial and some glacimarine deposits by currents (e.g., Anderson et al., 1980; Palmer et al., 2012). Although they may accumulate on the seafloor as ice-rafted sediments, they are difficult to identify as such and to isolate from the background sedimentation (e.g., Ruddiman, 1977). Silt is typically produced by glacial abrasion (Haldorsen, 1981) and may represent the terminal 
grade (i.e., minimum size) of many common rock forming minerals (Dreimanis and Vagners, 1971). Clay-size detritus is typically only a minor product of glacial erosion and some clay minerals, such as smectite, may also be precipitated in situ, thus complicating interpretations of clay separates (Singer, 1984). Unlike the pebble- and sand-fractions of glacigenic sediments, where individual grains or rock fragments can be identified, silts and clays are typically analyzed as a mixture. The very large number of individual grains analyzed in such mixtures minimizes the problem of collecting or analyzing enough grains to constitute a representative population. A challenge with interpreting provenance of the fines is that complex mixtures may have non-unique solutions and that, in Antarctica, some endmembers may be unknown because of the extensive ice cover making the origin of these size fractions difficult to interpret (e.g., Farmer and Licht, 2016).

\subsubsection{Clay Mineralogy}

Clay mineralogy has been interpreted as a paleoclimate proxy in Antarctic glacigenic sediments (i.e., Ehrmann et al., 2005), but has also been used to evaluate provenance of both subglacial and glacimarine sediments (Balshaw, 1980; Petschick et al., 1996; Yoon et al., 1992; Ehrmann et al., 2003; Giorgetti et al., 2009; Hillenbrand et al., 2009). Use of clay mineralogy for provenance is complicated by the fact that chemical weathering and diagenesis can alter clay minerals, altering the apparent sediment provenance (Setti et al., 1998). However, the relatively low rates of chemical weathering in Antarctica mean that clay mineralogy may be interpreted as an indicator of provenance when circumstances allow the two signals to be deconvolved (Ehrmann et al., 2003). An additional complication is that clay-sized material because it is not produced in large quantities through glacial comminution, so a reworked (recycled shale) component is common if only the clay fraction is considered (e.g., Passchier et al., 2016).

\subsubsection{Bulk geochemical and isotopic analysis}

Reported bulk geochemical analyses of Antarctic glacigenic sediments have included major, trace and rare earth elements, radiogenic isotopes, and X-ray fluorescence of discrete samples or using a core scanner (i.e., Passchier, 2004; Farmer et al., 2006; Hemming et al., 2007; Roy et al., 2007; van de Flierdt 
et al., 2007; Monien et al., 2012). Bulk analysis of radiogenic isotopes from long-lived parents (e.g., Nd, $\mathrm{Sr}, \mathrm{Pb}, \mathrm{Hf}$ ) on the $<0.063 \mathrm{~mm}$ fraction (or other more specific size fractions) of glacigenic sediments is a powerful approach to geochemical provenance analysis that has been widely used globally on sediments from many different types of terrigenous sediment settings. Provenance analysis using geochemical methods may reveal different elements of the sources and processes than detrital sand analysis, so the combination is valuable. As highlighted in Fig. 6, weakly indurated fine-grained sedimentary rocks are typically underrepresented in the sand fraction and are more likely to be incorporated into the silt- and/or clay-fractions (e.g., Passchier et al., 2016). Thus, the integrated geochemical signature of glacigenic sediments should provide a more representative sampling of bedrock sources, although they are still subject to the constraints of differential erosion on the subglacial landscape. Similar to the pebble- and sand-fractions, bulk geochemistry of glacigenic sediment may be used to determine whether a deposit has a local or exotic provenance. However, in some cases the bulk fine sediment fraction may not allow unique interpretations of source rocks (e.g., Farmer et al., 2006; Farmer and Licht, 2016) because the deposits are composed of complex mixtures with diverse endmembers. Distinctive tracers that are present in low abundance may be diluted and difficult to recognize. In time-series records (cores or moraine sequences), geochemical analyses of bulk fine sediments can be used to identify changes in source inputs over time with links to particular source rocks (e.g., Monien et al., 2012). Typically this type of analysis is done in the context of other provenance proxies, making the chemical signals easier to interpret. Bulk chemical data can also be used to calculate weathering proxies, such the chemical index of alteration (CIA) (e.g., Passchier, 2004).

Because of their complexity and particularly powerful application for tracing sediment sources, we give a more detailed summary of radiogenic isotope systems that have been used in bulk sediments around Antarctica in the following section.

\subsubsection{Radiogenic isotopes}


Radiogenic isotope systems (where radiogenic isotopes are here defined as the stable daughters of long-lived radioactive parents) in bulk terrigenous sediments are powerful and widely used tools for provenance analyses (see reviews in Goldstein and Hemming, 2003; Hemming, 2004; Grousset and Biscaye 2005). Glacigenic sediment isotopic signatures, as with all provenance proxies, are controlled by the geological histories of the sediments' sources as well as the sedimentary processes that bring them to their final depositional site. In general the radiogenic isotope compositions all of these systems are controlled by the integrated Parent/Daughter ratio (P/D) and are reported as ratios to a stable and nonradiogenic isotope of the daughter element. The commonly used radiogenic isotope ratios in bulk sedimentary materials are ${ }^{143} \mathrm{Nd} /{ }^{144} \mathrm{Nd}\left({ }^{147} \mathrm{Sm}\right.$ parent $),{ }^{87} \mathrm{Sr} /{ }^{86} \mathrm{Sr}\left({ }^{87} \mathrm{Rb}\right.$ parent $),{ }^{206} \mathrm{~Pb} /{ }^{204} \mathrm{~Pb},{ }^{207} \mathrm{~Pb} /{ }^{204} \mathrm{~Pb}$ and ${ }^{208} \mathrm{~Pb} /{ }^{204} \mathrm{~Pb}\left({ }^{238} \mathrm{U},{ }^{235} \mathrm{U}\right.$ and ${ }^{232} \mathrm{Th}$ parents $)$ and ${ }^{176} \mathrm{Hf} /{ }^{177} \mathrm{Hf}\left({ }^{176} \mathrm{Lu}\right.$ parent). For $\mathrm{Sm} / \mathrm{Nd}$ and $\mathrm{Lu} / \mathrm{Hf}$, the mantle (and basalt- note basalt will also have a lower P/D than its mantle source, but significantly higher than average continental rocks) is characterized by high $\mathrm{P} / \mathrm{D}$ and continental crust has low $\mathrm{P} / \mathrm{D}$ because of the greater compatibility of the parent in mantle melting (the parent preferentially stays in the solid residue relative to the daughter). Over time, after the continental crust forms, this relative P/D depletion leads to a progressively smaller increase in the proportion of the radiogenic daughter so continental sources have progressively more negative epsilon values (the epsilon notation is the parts per ten thousand deviation from CHUR (hondrite uniform reservoir), the assumed approximate composition of bulk Earth) for these radiogenic daughters with age since mantle extraction. The $\mathrm{Rb} / \mathrm{Sr}$ system has the opposite response during mantle melting, as the daughter is significantly more compatible during melting. Continental crust has a higher $\mathrm{Rb} / \mathrm{Sr}$ compared to the mantle and basalts, and this leads to progressively higher ${ }^{87} \mathrm{Sr} /{ }^{86} \mathrm{Sr}$ with aging continental rocks. Additionally, the difference in geochemical behavior of $\mathrm{Rb}$ and $\mathrm{Sr}$ during weathering and other sedimentary processes and metamorphism leads to a much greater dynamic range of ${ }^{87} \mathrm{Sr} /{ }^{86} \mathrm{Sr}$, and actual isotope values are usually reported rather than a delta or epsilon notation. A survey of $\mathcal{E}_{\mathrm{Nd}} \mathrm{Vs}{ }^{87} \mathrm{Sr} /{ }^{86} \mathrm{Sr}$ for Antarctic sediment samples is shown in Fig 8. 
It is also important to consider how sedimentary and metamorphic (rock cycle) processes may lead to variations in radiogenic isotope compositions of bulk sediments. For the $\mathrm{Pb}$ isotope system it is difficult to make generalizations (Hemming and McLennan, 2001) although there is a wide range of ratios for ${ }^{206} \mathrm{~Pb} /{ }^{204} \mathrm{~Pb}$ and ${ }^{208} \mathrm{~Pb} /{ }^{204} \mathrm{~Pb}$ and in some cases ${ }^{207} \mathrm{~Pb} /{ }^{204} \mathrm{~Pb}$ relative to the measurement uncertainty, and with the multiple isotope ratios this system is likely to be useful. For the $\mathrm{Sm} / \mathrm{Nd}$ system, it is widely assumed that by far the largest factor is mantle extraction, and to a good first approximation it can be assumed that other processes do not strongly influence the $\mathrm{Sm} / \mathrm{Nd}$, and thus the $\varepsilon_{\mathrm{Nd}}$ of sediments (e.g., McCulloch and Wasserburg, 1978; Taylor et al. 1983; Taylor and McLennan, 1985).

Hf is largely hosted within zircon in intermediate and felsic igneous rocks and their sedimentary and metamorphic derivatives. Although zircon has a strongly heavy rare earth element enriched pattern (Hanchar and Hoskin, 2003), and thus relatively high Lu concentrations, the Lu/Hf of zircon is so low that corrections for radiogenic ingrowth of ${ }^{176} \mathrm{Hf}$ in even very ancient zircons are very small. In addition to being hosted in zircon, Lu is hosted in other minerals, and is particularly concentrated in garnet and some other heavy minerals. Consequently weathering and transport processes lead to significant separation of the Hf that is produced by in-situ decay from the Hf that is hosted in zircon (e.g., van de Flierdt et al., 2007), leading to a tendency for the clay fraction to have a higher $\varepsilon_{\mathrm{Hf}}$ than silts and sands from the same provenance (with sediments from progressively older sources having progressively more extreme offsets). As clay is generally a minor component of glacigenic sediment, this fractionation effect should be minor.

\subsection{Multiproxy approaches}

While all of the approaches summarized above have demonstrated their value in providing significant insights into sediment provenance, the vagaries of each approach means that multiple approaches provide the most robust insights into the rock types eroded and processes that together produce glacigenic sediment. For example, the multiple thermochronology proxy provenance approach to the coarse sediment fraction is an excellent strategy for constraining the heritage (time of extraction from the mantle), geologic age (crystallization or high grade metamorphism) and denudation history (cooling 
through different temperatures) of sediments' sources. Examples include multiple thermochronologic measurements of different minerals from rock fragments and multiple thermochronological measurements $(\mathrm{U}-\mathrm{Pb}, \mathrm{FT},(\mathrm{U}-\mathrm{Th}) / \mathrm{He})$ on detrital grains of zircon, apatite and other U-bearing minerals (e.g. Thomson et al., 2012; Zattin et al., 2012; Tochilin et al., 2013; Welke et al., 2016). Detrital zircon studies have the most extensive range of approaches with SEM-imaging for shape and internal structure, trace element analysis for petrogenesis and crystallization temperature, oxygen isotope analysis, Hf isotope analysis, U$\mathrm{Pb}$, fission tracks and (U-Th)/He. Although prohibitive for routine provenance studies, such a combination on an individual crystal can provide the crystallization age and temperature of crystallization, information on the evolution of the magma's source from which the zircon crystallized, the type of rock that the zircon crystallized in, and information on when it last cooled through $\sim 200^{\circ} \mathrm{C}$ as well as how quickly it passed through that window. The research possibilities using this range of techniques have not yet been fully explored in Antarctica.

Multiple proxy approaches that integrate the geochemical information from different grain size fractions also provide important provenance insights. The multiple isotope systems combined with geochemistry and XRD mineralogy on the fine size-fractions help elucidate the nature of the mixing end members which can be useful for individual detrital grain interpretations. For example, if a sedimentary bedrock source, such as the Beacon Supergroup, is important in the catchment, tills derived from it would be expected to 1) contain few sand-sized hornblende, biotite, and apatite grains, but abundant (recycled and therefore likely abraded and rounded) quartz zircon grains; 2) provide abundant fines with compositions suggestive of chemical weathering processes (including enrichment of $\mathrm{Rb} / \mathrm{Sr}$ and very high ${ }^{87} \mathrm{Sr} /{ }^{86} \mathrm{Sr}$ if the sediment is old); and 3) be underrepresented in the pebble and cobble fraction if friable..

\section{Comparison of provenance approaches: case studies from the Ross Embayment}


A critical question in provenance analysis is 'Do all fractions of the sediment derive from the same sources?'. In the simplest cases, the answer is yes; studies of pebble, sand and silt/clay fractions from an ice-contact deposit should identify the same sources terranes from which the material was derived. However, as described in the section on subglacial processes, the answer is dependent on the spatial and textural variability in bedrock source material and the conditions at the base of the glaciers. Empirical results from provenance studies in Antarctica to date show a mixed answer to this key question. Here we present two case studies that highlight the possibility of different methods' yielding different aspects of (and thus potentially different interpretations if used in isolation) glacigenic sediment provenance.

4.1. Pebble lithology vs. detrital zircon $\mathrm{U} / \mathrm{Pb}$ age populations

At Mt. Achernar (Fig. 1), ice-cored moraines adjacent to nunataks at the edge of the polar plateau record quasi-continuous debris accumulation where debris is continually exposed at the surface in a manner analogous to a conveyor belt (Bader et al., in press). As with other ice-cored moraines, some debris in the moraine may originate in upstream regions of warm-based ice as indicated by faceted and striated rocks on the moraine surface. .Till and pebble samples were collected along a 5-km-long transect from the margin of Law Glacier back through progressively older and more distal areas of the moraine to assess provenance change over time. Distinct color banding (Fig. 10) and continuity of topographic ridges that are 1-12 $\mathrm{m}$ high and parallel to the moraine margin indicate that the moraine has been forming in an organized fashion over multiple glacial cycles (Kaplan et al., 2014). Generally, all pebbles are dominantly composed of Beacon Supergroup sedimentary rocks or Ferrar dolerite. The exception is a section located between 1 and $3 \mathrm{~km}$ from Law Glacier, which is associated with a broad topographic arch with surface exposure ages ranging from $\sim 12-50 \mathrm{ka}$ (Kaplan et al., 2014). Here the proportion of sedimentary rocks is more than double that in the rest of the moraine (Fig. 10), thus indicating a provenance change. However, the detrital zircon $\mathrm{U}-\mathrm{Pb}$ ages from the same samples (Fig. 10) show no major difference in this section of the moraine because the Ferrar dolerite is typically devoid of zircons. Thus a provenance study using only 
detrital zircons would have missed a significant change in till provenance. This highlights the importance of considering zircon fertility in source rocks (e.g., as emphasized by Moecher and Samson, 2006). The issue is not unique to zircons and would apply to other detrital minerals as well.

\subsection{Zircon populations vs. $\varepsilon_{\mathrm{Nd}}$ in the fine fraction}

Comparing data from individual grain measurements with data from homogenized mixtures of fine particles is necessary for reducing uncertainty in provenance interpretations of the fine fraction. In a source-to-sink provenance study tracing tills from lateral and nunatak moraines of the major East Antarctic outlet Byrd Glacier (Fig. 1) out on to the Ross Sea continental shelf, sand-sized detrital zircons, as well as the $\mathrm{Nd}, \mathrm{Sr}$ and $\mathrm{Pb}$ isotopic compositions of the silt/clay fraction of tills were analyzed from the same till samples ((Licht and Palmer, 2013; Farmer and Licht, 2016). Both datasets indicate that tills exposed along the Byrd Glacier today are predominantly derived from erosion of local bedrock, but that some nunatak moraines contain material transported from more distal locations beneath East Antarctic ice sheet. In contrast, the provenance of the fine-grained $(<63 \mathrm{~m})$ size fraction of LGM Ross Sea tills downstream of Byrd Glacier is ambiguous unless zircon geochronology data are considered. Specifically, the downstream Ross Sea tills have $\varepsilon_{\mathrm{Nd}}(0)-7.1$ to -12.5 and approximately equal populations of zircons $520-540$ and $560-600 \mathrm{Ma}$ (Fig. 11). The $\varepsilon_{\mathrm{Nd}}(0)$ could be simply explained by erosion of the Granite Harbor Intrusive rocks along the narrow part of the Byrd Glacier trough, however the zircon data are not consistent with this interpretation, as ages 560-600 Ma could not have been derived from these outcrops. Instead, $\varepsilon_{\mathrm{Nd}}(0)$ values of Ross Sea till most likely indicate that the fine-grained sediments represent the mixture of glacial sediment produced along the entire path of the Byrd Glacier through the TAM including Granite Harbor Intrusive rocks and upstream rock types that have a very wide range of $\varepsilon_{\mathrm{Nd}}(0)$ values, -6 from the Ferrar dolerite, $>-15$ for Beacon Supergroup rocks and -25 to -30 from Miller Range Precambrian basement.. The data reveal the involvement of high $\varepsilon_{\mathrm{Nd}}(0)\left(\right.$ low $\left.{ }^{87} \mathrm{Sr} /{ }^{86} \mathrm{Sr}\right)$, zircon-free mafic lithologies such as the Ferrar dolerites or Cenozoic McMurdo volcanic rocks that are invisible as far as 
detrital zircon provenance determinations are concerned. The involvement of upstream rocks is best illustrated by the fact that the central Ross Sea tills contain zircon grains with U-Pb ages from 560-600 Ma that could only have been derived from bedrock in this portion of the Byrd Glacier. These data illustrate that radiogenic isotopic data and zircon $\mathrm{U}-\mathrm{Pb}$ information together provide a more complete picture of the provenance of a given till than either technique alone.

\section{Examples ranging from source to sink}

\subsection{Catchment scale source area studies}

Representative pebble populations have been used in surficial glacigenic deposits from outlet glaciers in the Ross Embayment to identify provenance changes and spatial variations in glacial transport processes at Byrd Glacier (Palmer et al., 2012), Mt. Achernar (Bader et al., in press), and Reedy Glacier (Kramer, 2008). For such studies, the representative population is determined by collecting all coarse to very coarse pebbles from $1 \mathrm{~m}^{2}$ areas. The ice-cored moraines at Byrd Glacier (Fig. 1) lack a clear stratigraphic sequence, but provide constraints on erosion and till transport processes. Pebbles collected from the surface of moraines are used to evaluate the proportion that originates from exotic rock types. These data, and the radiogenic isotope data (Farmer and Licht, 2016) show that most ice-cored moraines along the valley walls and at the base of nunataks are dominated by locally-derived material lacking evidence of glacial abrasion. However, the moraine at Lonewolf Nunataks contains up to $65 \%$ exotic pebbles and 25-45\% of pebbles show signs of abrasion (facets/striations) (Fig. 15) (Palmer et al., 2012), as well as low $\varepsilon_{\mathrm{Nd}}(0)$ indicating contribution from unexposed basement rocks. A possible explanation for this greatly increased exotic contribution is that the subglacial topography upstream of Lonewolf Nunataks has significant bed roughness (Gogineni et al., 2014); this is likely to be a first-order control on entrainment and deposition. This example highlights the variety of parameters that need to be considered in understanding till provenance. 
The provenance of distinctive pebbles/cobbles in surficial glacial deposits may also be used for reconstructing past ice flow paths. For instance, glacial geologic studies in the McMurdo Dry Valleys revealed the presence of kenyte erratics. Kenyte is an uncommon porphyritic phonolite with large euhedral anorthoclase crystals. The presence of kenyte in glacigenic sediments has been used to document LGM ice flow lines in the southwestern Ross Sea (Denton and Marchant, 2000; Hall and Denton, 2000) that bring ice from the south, wrap in a westerly direction around Ross Island reaching the western flank of Mt. Erebus, and finally extending up into the mouth of valleys.

The characteristics of individual rocks has been used to provide constraints on the existence of subglacial outcrops that are presently covered by ice in the Transantarctic Mountains. Goodge et al. (2008) reported geochemical and geochronological details of a granitic erratic collected from a nunatak moraine near Nimrod Glacier, and made that case that the clast is a unique match with Laurentian granites. They used this match to infer the existence of a previously unmapped geologic terrane upstream of the moraine that was connected with the southwestern United States at $1.4 \mathrm{Ga}$, thus providing important information on East Antarctica's position in the Rodinian supercontinent. Other igneous erratics collected from nunatak moraines and analyzed with zircon geochronology confirm the existence of unexposed Grenville-age crust inland of the Transantarctic Mountains (Goodge et al., 2010), further consistent with the hypothesized connection between East Antarctica and the southwestern U.S.

\subsection{Source to sink in the Ross and Weddell Embayments}

The Ross and Weddell Seas are major embayments in the Antarctic perimeter that are fed by glaciers from both East and West Antarctic ice sheets. A primary motivation for being able to discriminate past fluctuations of the East and West Antarctic ice sheets is the difference in the physical setting of these two major ice sheets, which leads to differences in sensitivity to climate change and associated sea level fluctuations. The inward sloping bed topography that characterizes much of West Antarctica has long been thought to make it susceptible to rapid, progressive retreat (i.e., Hollin, 1962) and there is increasing evidence that such retreat is currently underway here and along the Antarctic 
Peninsula (Joughin et al., 2014; Rignot et al., 2014; Christie et al., 2016). A second motivation is that ice streams carry the main flux of ice out of the Antarctic interior, thus they play a key role in ice sheet stability. Accordingly, understanding their past role in ice sheet behavior is essential to creating accurate ice sheet reconstructions that help inform continental-scale numerical modeling efforts (i.e., Golledge et al., 2013). In the Ross Embayment, West Antarctic ice input is dominated by the Siple Coast ice streams with relatively unconstrained margins, whereas East Antarctic ice is physically constrained by deep and narrow outlets through the Transantarctic Mountains (Fig. 1). These differing physical constraints are likely important factors in relative ice volume contributions by East and West Antarctica. The Weddell Embayment also contains ice streams originating from both East and West Antarctica (Fig. 1) where complex physical factors control individual ice stream responses to external forcing (Wright et al., 2014). Here we review the application of a variety of source-to-sink provenance approaches used to identify East and West Antarctic derived ice in the Ross and Weddell Embayments.

Initial models of LGM ice flow in the Ross Embayment included Siple Coast ice stream from West Antarctic extending across the continental shelf (i.e., Stuiver et al., 1981). Analysis of sand petrography from tills across the continental shelf identified seven lithologic provinces (Anderson et al., 1984) that were linked to bedrock exposures in the Transantarctic Mountains and Marie Byrd Land to construct ice flow lines. Later, more comprehensive sample sets allowed the application of source-to-sink provenance studies to evaluate the reconstruction by Stuiver et al. (1981) using tills from moraines in the Transantarctic Mountains, subglacial tills collected beneath Siple Coast ice streams, and LGM-age tills from the continental shelf (Licht et al., 2005; Farmer et al., 2006). Although samples from Transantarctic Mountains were sparse at the time of these studies, sand petrography and radiogenic isotopic analyses both indicated mixing of glacial debris derived from both East Antarctic Ice Sheet (EAIS) and West Antarctic Ice Sheet (WAIS) in the central Ross Sea. WAIS-dominated ice flow reconstructions are not consistent with the observed LGM sediment compositions. 
Following the discovery of significant EAIS contributions to the LGM Ross Ice Sheet, more extensive sampling of moraines along major outlet glaciers and application of detrital mineral geochronology along with additional petrographic and radiogenic isotope work revealed several new findings. One is that much of the West Antarctic basin fill burying the rift-related mafic rocks has a very similar provenance signature to till in the Transantarctic Mountains, making EAIS and WAIS till differentiation difficult. The petrography of ice stream tills is very similar to Reedy Glacier tills, with minor differences in the mineral to rock fragment ratio (Kramer, 2008). The U-Pb ages of detrital zircons in these same tills provide a more distinctive tracer. For example, Kamb and Bindschadler ice stream tills, with a particularly distinctive minor population of Cretaceous-age grains (100-110 Ma), can be traced to LGM tills on the continental shelf (Fig. 14). Grains of this age are totally absent from the $\sim 2800$ zircons measured from Transantarctic Mountains tills (Licht et al., 2014), and are found in the Ross Sea only east of $180^{\circ}$ longitude. In contrast, Whillans ice stream till and most samples from the Transantarctic Mountains are dominated by Ross/Pan-African zircons (480-600Ma) originating from Beacon Supergroup rocks and the Granite Harbor Intrusives (Licht et al., 2014) making the WAIS and EAIS indistinguishable from each other with this method. Zircon double-dating, following the approach of Reiners (2005), was tested as an additional strategy to differentiate East and West Antarctic derived grains from the ubiquitous Ross/Pan-African population, but both the U-Pb and the (U-Th)/He populations from the two areas overlap (Welke et al., 2016).

The geography of the Weddell Embayment is substantially different from the Ross Embayment, as fast flowing ice from both the EAIS and WAIS margins of the Weddell Embayment are more strongly controlled by topography (Fig. 1). Inputs from the WAIS are limited by the high elevation of the Ellsworth Mountains and surrounding terrain. Source-to-sink provenance studies of glacigenic sediments have not yet been completed in the Weddell Sea Embayment, but analyses of sand petrography in offshore glacigenic sediments and $\mathrm{Pb}$ isotopes in feldspars from bedrock samples reveal important regional variations in provenance that are useful for assessing WAIS vs. EAIS inputs (Anderson et al., 
1991; Diekmann and Kuhn, 1999; Flowerdew et al., 2012). A particular challenge in this area has been the persistent ice cover in the southwestern Weddell Sea, which has severely limited sample collection of sediments adjacent to the WAIS. Anderson et al. (1991) analyzed the pebble and sand fraction of till and ice-proximal glacimarine sediment from cores in the eastern Weddell Sea and found distinct provinces that could be tied to outcrops, and these distinct populations allowed them to draw LGM ice flowlines. They also suggested that the exposed outcrops in Coats and Dronning Maud Land were not representative of the subglacial geology. Analysis of heavy minerals in the sand fraction of surface sediments from a wider area of the Weddell Sea showed similar spatial variability but also the lack of a clear WAIS provenance signal in the western Weddell Sea (Diekmann and Kuhn, 1999). Pierce et al. (2014) found several distinctive age populations in detrital grains from near surface core samples derived from EAIS sources in the Weddell Sea (Figs. 12,13) although WAIS sources within the Weddell Sea are not represented in this survey.

An emerging strategy for provenance is the $\mathrm{Pb}$ isotope composition of detrital feldspars. $\mathrm{Pb}$ isotopic analyses of feldspars from bedrock samples around the Weddell Embayment highlight distinct differences between the Antarctic Peninsula, WAIS- and EAIS source terrains (Flowerdew et al., 2012) suggesting that similar analysis in glacigenic sediments may produce useful provenance information about ice inputs from these areas. So far the published applications are for Permian sedimentary rocks (Flowerdew et al., 2012) and basement rocks (Flowerdew et al., 2012, 2013). Flowerdew et al., (2012) make the case that West Antarctic sources can be clearly distinguished from East Antarctic sources based on their $\mathrm{Pb}$ isotope compositions, and that by combining the $\mathrm{Pb}$ isotope composition of feldspar with $\mathrm{U} / \mathrm{Pb}$ ages of detrital zircons, it is possible to infer first cycle versus multiple cycle sources. Flowerdew et al. (2013) showed that within the region around Prydz Bay, which is dominated by ca 500 Ma ages, the $\mathrm{Pb}$ isotopes fall into distinct compositional fields, elucidating connections with conjugate margins as well as terranes that do not appear to extend out of Antarctica. Although there is not yet a published circum- 
Antarctic survey of Pb isotopes in feldspars, two papers (Flowerdew et al., 2012; 2013) make a strong case that this would be a powerful provenance approach.

\subsubsection{Long temporal-scale provenance records from the Ross Embayment}

Most provenance work to date has either identified spatial patterns in glacigenic sediment provenance using multiple proxies over a limited time frame (i.e., LGM, modern surface sediments) or focused on detrital minerals of the sand fraction over longer timescales in offshore cores. Some exceptions to this pattern include both terrestrial (Porter and Beget, 1981; Bader et al., in press) and marine provenance studies from long, continuous records. For example, the sediment provenance of ANDRILL and Cape Roberts cores have been exceptionally well studied and included analysis of a wide variety of provenance methods that have been used in conjunction with other climate proxies to assess ice sheet stability over millions of years (e.g., Barrett, 2007; Naish et al., 2009). Cores of glacigenic sediments around the Antarctic margin typically lack a sufficient number of pebbles to be evaluated with a population level analysis of provenance. An exception is the detailed characterization of gravel in the ANDRILL AND-1B drill core collected beneath the McMurdo Ice Shelf spanning the Late Pleistocene to the Late Miocene (Talarico and Sandroni, 2009; Talarico et al., 2010). Here, all gravel in one-meter-long sections were combined and included in analysis where $>10$ clasts $/ \mathrm{m}$ occurred. In a herculean effort, almost 120,000 individual clasts were identified. In the lowest section of the core (Miocene), clasts in diamicts show provenance attributed to a Byrd-Carylon Glacier source and shift to a Mulock-Skelton Glacier provenance source for the remainder of the core (Talarico and Sandroni, 2009). This material is diluted to varying degrees (sometimes $100 \%$ ) by input from emerging volcanic centers. In the upper part of the core, the Late Pleistocene-Pliocene core sections show continued input from the regions of MulockSkelton Glaciers but a decline in volcanic debris (Talarico et al., 2010) (Fig. 16). These time-series studies highlight the importance of changing paleotopography, especially in volcanically active areas. This analysis on the pebble fraction complements several other provenance studies on the same core, as well as provenance work on a nearby core, ANDRILL AND-2A, and collectively these studies showcase 
the value of long temporal provenance records for understanding both ice sheet and landscape changes over time (Giorgetti et al., 2009; Talarico et al., 2011; Hauptvogel and Passchier, 2012, Zattin et al., 2012). Additionally, the magnetic mineralogy and thermomagnetic signature of sediment in these cores demonstrates the provenance potential of this set of emerging techniques (Brachfeld et al., 2013).

\subsection{Provenance studies of offshore sediment sinks}

Several offshore continent-scale or large regional surveys using radiogenic isotopes and geochronology in Late Pleistocene glacimarine sediment around Antarctica's perimeter highlight the broad potential for provenance applications to understand Antarctica's ice sheets through time. Such studies depend on data from basement outcrops (e.g., Fitzsimons, 2000) and tills (e.g., Anderson et al., 1991; Farmer et al., 2006; Licht et al., 2014) to aid in interpretations. The first circum-Antarctic multiproxy dataset was from thirty core-top samples from sediment cores around Antarctic, combining ${ }^{40} \mathrm{Ar} /{ }^{39} \mathrm{Ar}$ on detrital hornblende grains and $\varepsilon_{\mathrm{Nd}(0)}$ on the $<63 \mu \mathrm{m}$ bulk detritus fraction (Roy et al., 2007) with $\varepsilon_{\mathrm{Nd}(0)}$ (van de Flierdt et al., 2007) and ${ }^{87} \mathrm{Sr} /{ }^{86} \mathrm{Sr}$ (Hemming et al., 2007). Pierce et al. (2014) greatly expanded the survey of detrital grains, compiled the published on-land geological evidence, and compared detrital hornblende ${ }^{40} \mathrm{Ar} /{ }^{\beta 9} \mathrm{Ar}$, biotite ${ }^{40} \mathrm{Ar} /{ }^{39} \mathrm{Ar}$, and zircon $\mathrm{U} / \mathrm{Pb}$ ages around Antarctica. There is good general agreement with and on-land geochronology and with previous provenance studies, but there are some interesting exceptions, especially along the Wilkes Land sector (Figs. 12 and 13). Apparent contradictions provide opportunites for further studies to explore the possibility of better understanding hidden subglacial geology (e.g., Cook et al., 2013; Cook et al., submitted), but the possibility of variations in sediment dispersal must also be considered.

Collectively these studies show clear spatial patterns in proximal circum-Antarctic sediment cores, including a distinction between East and West Antarctica, where East Antarctica has older ${ }^{40} \mathrm{Ar} /{ }^{39} \mathrm{Ar}$ ages as well as lower $\varepsilon_{\mathrm{Nd}}(0)$ and $\varepsilon_{\mathrm{Hf}}(0)$ and higher ${ }^{87} \mathrm{Sr} /{ }^{86} \mathrm{Sr}$. Although a very large part of East Antarctica is characterized by ${ }^{40} \mathrm{Ar} /{ }^{39} \mathrm{Ar}$ ages of near $500 \mathrm{Ma}$ from the Pan-African or Ross Orogens, the Wilkes Land margin contributes significantly older ages (like its Australian conjugate margin), and the 
texture of $\varepsilon_{\mathrm{Nd}}(0)$ (and $\varepsilon_{\mathrm{Hf}}(0)$ and higher ${ }^{87} \mathrm{Sr} /{ }^{86} \mathrm{Sr}$ ) variations of bulk sediment combined with ${ }^{40} \mathrm{Ar} /{ }^{39} \mathrm{Ar}$ populations allows further distinction among the different ice sheet sectors.

5.3.1 Time series of IRD in circum-Antarctic marine sediment cores from the last glacial cycle

Provenance applications to down core records of glacigenic sediment have revealed the significant potential for understanding Antarctica's ice sheets' histories on many timescales. Kanfoush et al. (2000) examined the abundance of ice-rafted detritus (IRD) between 20 and $74 \mathrm{ka}$ in three cores from the South Atlantic Ocean, along a transect from $53^{\circ}$ to $41^{\circ} \mathrm{S}$. They found millennial scale variability that appears to be approximately synchronous in a core north of the sub-Antarctic front and a core south of the Polar front, but found additional peaks in the intermediate core that they interpreted to possibly reflect movements of the fronts. The composition of the IRD in these South Atlantic sites is a mix of volcanic debris and continental fragments, mostly quartz but including granitic rock fragments and mica. The proportion of total IRD to quartz varies considerably in the records. In a follow-up study Nielsen et al. (2007) measured the compositions of volcanic glass grains (as well as some feldspar and olivine grains) and concluded that most of the material was derived from the Scotia Arc. The inference from both of these studies is that the volcanic material was erupted onto sea ice and then transported in the circumAntarctic current to be deposited at the sites- in such a situation it would be expected that the availability of erupted material, the sea surface temperature and current paths might all contribute to the abundance of the volcanic IRD component. This should actually be an advantage for establishing time lines among the cores, although it is somewhat of a complication for understanding the climatic significance. No followup studies of the continental detritus are published, but it would certainly be of interest to delve into the continental contribution.

Weber et al. (2014) presented iceberg rafted detritus abundance and flux estimates at high resolution through the last deglaciation in two cores from "iceberg alley" in the Scotia Sea. They used xray imaging to count the number of grains $>1 \mathrm{~mm}$ through the cores. The largest peak is $15-14 \mathrm{ka}$, and the authors make the case that this is evidence for a significant Antarctic contribution to meltwater pulse 
1A. The authors weave a case for a general EAIS contribution due to the cold conditions of the Antarctic counter current, allowing icebergs to survive around Antarctica until they enter the Weddell gyre and travel into the Antarctic Circumpolar Current where they melt quickly. This is a clear case where sedimentary provenance analyses could greatly aid understanding what parts of Antarctica contributed to the pulses of iceberg rafted detritus.

5.3.2. Time series of IRD in circum-Antarctic marine sediment cores from long-term records

Although constrained by the realities of core recovery and time-scale development, significant discoveries have come from the study of ice-rafted detritus provenance on long time scales around Antarctica. Early studies from Ocean Drilling Program cores documented the first Cenozoic continental scale glaciation on Antarctica at approximately the Eocene-Oligocene boundary (e.g., Kennett, 1977; Barker et al., 1988; Barron et al., 1991; Zachos et al., 1992). Since that time, provenance application of radiogenic isotopes and detrital thermochronometers has also contributed to an understanding of the Cenozoic evolution of Antarctic glaciation (e.g., Williams et al., 2010; Cook et al., 2013, 2014; Tochilin et al., 2012; Thomson et al., 2013).

One example of the application of detrital thermochronology comes from the work of Williams et al. (2010), who following up on the early study of Roy et al. (2007), studied the ice rafted detritus record from ODP 1165 near Prydz Bay where Passchier (2011) had documented the IRD flux. They found that in deposits younger than $15 \mathrm{Ma}$, a significant fraction of hornblende grains have ${ }^{40} \mathrm{Ar} /{ }^{39} \mathrm{Ar}$ ages implying that were derived from $>2000 \mathrm{~km}$ away on the Wilkes Land margin (Fig. 17). Site 1165 records many instances of large fluxes from the Wilkes Land margin (Williams et al., 2010; Cook et al., 2014), likely related to destabilization of ice in the Wilkes Subglacial Basin, which has a large area that is significantly below sea level and is thus considered vulnerable to collapse (e.g., Pollard et al, 2015). Pierce et al. (2011) increased the spatial resolution of hornblende ${ }^{40} \mathrm{Ar} /{ }^{39} \mathrm{Ar}$ from proximal samples around the Prydz Bay-Wilkes Land part of the Antarctic margin, confirming the provenance conclusion of Williams et al. (2010). Cook et al. (2014) reported ${ }^{40} \mathrm{Ar} /{ }^{39} \mathrm{Ar}$ hornblende ages from many more layers in ODP 1165 
through the Pliocene and additionally used iceberg transport modeling to ground-truth the core top provenance and to suggest that part (but certainly not all) of the explanation for the high abundance of fartravelled grains is related to sea surface temperature controls on iceberg survival (Fig. 18).

Another example of gaining understanding of subglacial geology, as well as erosion related to ice sheet development, comes from multiple-thermochronometry approaches of detrital grains from ODP sites in Prydz Bay. Using radiogenic isotopes and a variety of detrital thermochronometers, van de Flierdt et al. (2008) were able to demonstrate modest variability in the provenance of sediment deposited at site 1166 in Prydz Bay, from fluvial Cretaceous sediments through late Cenozoic glacigenic sediments. Cox et al. (2010) used the pre-glacial sands to show, with double-dated apatite, that the erosion within the entire Lambert catchment was very slow, and Tochilin et al. (2012) and Thomson et al. (2013) made an extensive record of double- and triple-dated detrital apatite grains in sites 739 and 1166, respectively, that demonstrated a rapid incision event close to the initiation of Antarctic glaciation at the Eocene-Oligocene boundary.

\section{Summary}

Understanding of Antarctica's ice sheet history has increased significantly because of the increasing focus on provenance studies over the past decade. A wide array of provenance tools has been applied to Antarctic studies, and other emerging tools also show promise. Although most of Antarctica is ice covered, we can still make sense of offshore provenance records in IRD and till. Because of the fortuitous distribution of geology around Antarctica it is possible to use provenance approaches to understand what parts of the continent were contributing significant discharges of icebergs to the ocean from the modern back through much of the Cenozoic. Additionally, much has been made of the differences between the behavior and sensitivity of the East and West Antarctic ice sheets. Provenance data from glacigenic sediment have allowed assessment of the behavior of these two ice masses and, for example in the Ross Embayment, show West Antarctic derived ice only constituted about half the Ross 
Ice Sheet during the LGM. Findings such as these have shaped numerical modeling efforts for elucidating ice sheet behavior, improving the robustness of model output.

In addition to providing key information about Antarctica's ice sheets, glacigenic deposits contain valuable information about glacial erosion and the bedrock buried beneath glacier ice that are otherwise inaccessible. For instance, application of low-temperature detrital thermochronometers provides a tool to assess erosion rates through time and evaluate the thermal history of bedrock buried in a glacier's catchment. Multiproxy studies show that during the LGM, East Antarctic outlet glaciers transported and deposited mixtures of sediment derived from both the ice sheet interior and the narrow valleys. This observation, combined with model reconstructions showing spatially variable erosion rate and sediment flux, is important to consider in interpreting the provenance of offshore glacigenic sediments. Several studies have highlighted how rock type and particle size may influence the proportional contributions to sedimentary archives and therefore, provenance studies should consider and select analysis techniques that allow identifying the full spectrum of provenance components or acknowledge the types of rocks that would be cryptic in the applied approach. Finally, we conclude that provenance techniques are most reliable when a multi-proxy approach is followed.

\section{Acknowledgements}

The work was supported by grants to Licht by NSF-OPP/ANT (0003600, 0440885, 0944578, 1043572, $1342251)$ and Hemming by NSF-OPP/ANT (0088054, 0538580, 0838722, 0944489, 1342213). We are grateful to the graduate and undergraduate students and post docs who were key contributors to our research efforts. Our views and understanding have been greatly facilitated by discussions with our collaborators on different aspects of Antarctic sediment provenance, specifically L. Farmer, S. Goldstein, P. Reiners, S. Thomson, T. van de Flierdt, and T. Williams. J.T. Andrews provided a helpful informal review of the manuscript. R. Schmitt provided bedrock geology data from the Gondwana Map project 
IGCP-628 and C. Kassab transformed it into Figure 3. We are grateful to S. Passchier and an anonymous reviewer for their thoughtful comments, which improved the manuscript. 


\section{References}

Anderson, J.B., Kurtz, D.D., Domack, E.W., Balshaw, K.M., 1980. Glacial and glacial-marine sediments of the Antarctic continental shelves. Journal of Geology 88, 399-414.

Anderson, J.B., Brake, C.F., Myers, N.C., 1984. Sedimentation on the Ross Sea continental shelf, Antarctica. Marine Geology 57, 295-333.

Anderson, J.B., Andrews, B.A., Bartek, L., Truswell, E.M., 1991. Petrology and palynology of Weddell Sea glacial sediments: implications for subglacial geology. In: Thomson, M.R.A., Crame, J.A., Thomson, J.W. (Eds.), The Geological Evolution of Antarctica. Cambridge University Press, New York, pp. 231235.

Anderson, J.B., Shipp, S.S., Bartek, L.R., Reid, D.E., 1992. Evidence for a grounded ice sheet on the Ross Sea continental shelf during the Late Pleistocene and preliminary paleodrainage reconstruction. Antarctic Research Series 57, 39-62.

Andrews, J.T., Sim, V.W., 1964. Examination of the carbonate content of drift in the area of Foxe Basin, N.W.T. Geography Bulletin 21, 44-53.

Atkins, C.B., Barrett, P.J., Hicock, S.R., 2002. Cold glaciers erode and deposit: Evidence from Allan Hills, Antarctica. Geology 30, 659-662.

Bader, N.A., Licht, K.J., Kaplan, M.R., Kassab, C., and Winckler, G., in press. East Antarctic ice sheet stability since the mid-Pleistocene recorded in a high-elevation ice cored moraine. Quaternary Science Reviews.

Balshaw K.M., 1981. Antarctic glacial chronology reflected in the Oligocene through Pliocene sedimentary section in the Ross Sea (PhD thesis). Rice University, Houston, 140 p.

Barker, P.F., Kennett, J.P., et al., 1988. Proceedings, Ocean Drilling Program, Initial Reports 113, 785 p.

Barrett, P.J., 1991. The Devonian to Jurassic Beacon Supergroup of the Transantarctic Mountains and correlatives in other parts of Antarctica. In: Tingey, R.J. (Ed.), The Geology of Antarctica. Oxford University Press, New York, pp. 120-152.

Barrett, P., 2007. Cenozoic climate and sea level history from glacimarine strata off the Victoria Land coast, Cape Roberts Project, Antarctica. In: Hambrey, M.J., Christoffersen, P., Glasser, N.F., Hubbard, B., (Eds.), Glacial Sedimentary Processes and Products, Special Publication 39 of the International Association of Sedimentologists. Blackwell Publishing, Ltd., Oxford, UK. doi: 10.1002/9781444304435.ch15.

Barron, J., Larsen, B., Baldauf, J.G., 1991. Evidence for late Eocene to early Oligocene Antarctic glaciation and observations on late Neogene glacial history of Antarctica: results from leg 119. In: Barron, J., Larsen, et al., (Eds.), Proceedings of the Ocean Drilling Program, Scientific Results, 119, pp. 869-891. 
Bell, R.E., Ferracciolli, F., Creyts, T.T., Braaten, D., Corr, H., Das, I., Damaske, D., Frearson, N., Jordan, T., Rose, K., Studinger, M., Wolovick, M., 2011. Widespread persistent thickening of the East Antarctic ice sheet by freezing from the base. Science 331, 1592-1595.

Bernet, M., Garver, J.I., 2005. Fission-track analysis of detrital zircon. Reviews in Mineralogy and Geochemistry 58, 205-237.

Boulton, G.S., 1978. Boulder shapes and grain-size distributions of debris as indicators of transport paths through a glacier and till genesis. Sedimentology 25, 773-799.

Brachfeld, S., Pinzon, J., Darley, J., Sagnotti, L., Kuhn, G., Florindo, F., Wilson, G., Ohneiser, C., Monien, D., Joseph, L., 2013. Iron oxide tracers of ice sheet extent and sediment provenance in the ANDRILL AND-1B drill core, Ross Sea, Antarctica. Global and Planetary Change 110, 420-433.

Christie, F.D.W., Bingham, R.G., Gourmelen, N., Tett, S.F.B., Muto, A., 2016. Four-decade record of pervasive grounding line retreat along the Bellingshausen margin of West Antarctica. Geophysical Research Letters 43, 5741-5749, doi:10.1002/2016GL068972

Christoffersen, P., Tulaczyk, S., Behar, A., 2010. Basal ice sequences in Antarctic ice stream: Exposure of past hydrologic conditions and a principal mode of sediment transfer. Journal of Geophysical Research 115, F03034, doi:10.1029/2009JF001430.

Church, J.A., Clark, P.U., Cazenave, A., Gregory, J.M., Jevrejeva,S., Levermann, A., Merrield, M.A., Milne, G.A., Nerem, R.S., Nunn, P.D., Payne, A.J., Pfeffer, W.T., Stammer, D., Unnikrishnan, A.S., 2013. Sea Level Change. In: Stocker, T.F., D. Qin, G.-K. Plattner, M. Tignor, S.K. Allen, J. Boschung, A. Nauels, Y. Xia, V. Bex and P.M. Midgley (Eds.), Climate Change 2013: The Physical Science Basis. Contribution of Working Group I to the Fifth Assessment Report of the Intergovernmental Panel on Climate Change. Cambridge University Press, Cambridge, United Kingdom and New York, NY, USA.

Clark, P.U., 1987. Subglacial sediment dispersal and till composition. Journal of Geology 95, 527-541.

Cook, C.P., van de Flierdt, T., Williams, T., Hemming, S.R., Iwai, M., Kobayashi, M., Jimenez-Espejo, F.J., Escutia, C., Gonzalez, J.J., Khim, B.K., McKay, R.M., Passchier, S., Bohaty, S.M., Riesselman, C.R., Tauxe, L., Sugisaki, S., Galindo, A.L., Patterson, M.O., Sangiorgi, F., Pierce, E.L., Brinkhuis, H., Scientists, I.E., 2013. Dynamic behaviour of the East Antarctic ice sheet during Pliocene warmth. Nature Geoscience 6, 765-769.

Cook, C.P., Hill, D.J., Flierdt, T., Williams, T., Hemming, S.R., Dolan, A.M., Pierce, E.L., Escutia, C., Cortese, G., Gonzales, J.J., 2014. Sea surface temperature control on the distribution of far-traveled Southern Ocean ice-rafted detritus during the Pliocene. Paleoceanography 29, 533-548.

Cook A.J., Holland, P.R., Meredith, M.P., Murray, T., Luckman, A., Vaughan, D.G., 2016. Ocean forcing of glacier retreat in the western Antarctic Peninsula. Science 353, 283-286.

Cox, S.E., Thomson, S.N., Reiners, P.W., Hemming, S.R., van de Flierdt, T., 2010. Extremely low longterm erosion rates around the Gamburtsev Mountains in interior East Antarctica. Geophysical Research Letters, doi:10.1029/2010GL045106. 
Curtis, M.L., Millar, I.L, Storey, B.C., Fanning, M., 2004. Structural and geochronological constraints of early Ross orogenic deformation in the Pensacola Mountains, Antarctica. Geological Society of America Bulletin 116, 619-636.

Dahl, P.S., 1996. The effects of composition on retentivity of argon and oxygen in hornblende and related amphiboles: a field-tested empirical model. Geochimica et Cosmochimica Acta 60, 3687-3700.

Damiani, D., Giorgetti, G., 2008. Provenance of glacial-marine sediments under the McMurdo/Ross Ice Shelf (Windless Bight, Antarctica): Heavy minerals and geochemical data. Palaeogeography, Palaeoclimatology, Palaeoecology 260, 262-283.

Denton, G.H., Marchant, D.R., 2000. The geologic basis for a reconstruction of a grounded ice sheet in McMurdo Sound, Antarctica, at the last glacial maximum. Geografiska Annaler: Series A, Physical Geography 82, 167-211.

Dickinson, W.R., 1970. Interpreting detrital modes of graywacke and arkose. Journal of Sedimentary Petrology 40, 695-707.

Diekmann, B., Kuhn, B., 1999. Provenance and dispersal of glacial-marine surface sediments in the Weddell Sea and adjoining areas, Antarctica: ice-rafting versus current transport. Marine Geology 158, 209-231.

Domack, E.W., 1982. Sedimentology of glacial and glacial marine deposits on the George V-Adelie continental shelf, East Antarctica. Boreas 11, 79-97.

Dreimanis, A., Vagners, U.J., 1971. Bimodal distribution of rock and mineral fragments in basal tills. In: Goldthwait, R.P., (Ed.), Till: A Symposium. Ohio State University Press, Columbus, Ohio, pp. 237-250

Ehrman, W., Bloemendal, J., Hambrey, M.J., McKelvey, B., Whitehead, J., 2003. Variations in the composition of the clay fraction of the Cenozoic Pagodroma Group, East Antarctica: implications for determining provenance. Sedimentary Geology 161, 131-152.

Ehrman, W., Setti, M., Marinoni, L., 2005. Clay minerals in Cenozoic sediments off Cape Roberts (McMurdo Sound, Antarctica) reveal palaeoclimatic history. Palaeogeography, Palaeoclimatology, Palaeoecology 229, 187-211.

Elliot, D.H., Fanning, C.M., 2008. Detrital zircons from upper Permian and lower Triassic Victoria Group sandstones, Shackleton Glacier region, Antarctica: evidence for multiple sources along the Gondwana plate margin. Gondwana Research 13, 259-274.

Elliot, D.H., Fanning, C.M., Hulett, S.R., 2014. Age provinces in the Antarctic craton: Evidence from detrital zircons in Permian strata from the Beardmore Glacier region, Antarctica. Gondwana Research 28, 152-164.

Elsner, M., Schöner, R., Gerdes, A., Gaupp, R., 2013. Reconstruction of the early Mesozoic plate margin of Gondwana by U-Pb ages of detrital zircons from northern Victoria Land, Antarctica. In: Harley, S.L., Fitzsimons, I.C.W., Zhao, Y., (Eds.), Antarctica and supercontinent evolution. Geological Society Special Publications, London, 237 pp. 
Farmer, G.L., Licht, K., 2016. Generation and fate of glacial sediments in the central Transantarctic Mountains based on radiogenic isotopes and implications for reconstructing past ice dynamics. Quaternary Science Reviews 150, 98-109.

Farmer, G.L., Licht, K., Swope, R.J., Andrews, J., 2006. Isotopic constraints on the provenance of finegrained sediment in LGM tills from the Ross Embayment, Antarctica. Earth and Planetary Science Letters 249, 90-107.

Fitzsimons, I.C.W., 2000. Grenville-age basement provinces in East Antarctica: Evidence for three separate collisional orogens. Geology 28, 879-882.

Flowerdew, M.J., Millar, I.L., Curtis, M.L., Vaughan, A.P.M., Horstwood, M.S.A., Whitehouse, M.J., Fanning, C.M., 2007. Combined U-Pb geochronology and Hf isotope geochemistry of detrital zircons from early Paleozoic sedimentary rocks, Ellsworth-Whitmore Mountains block, Antarctica. Geological Society of America Bulletin 119 (3-4), 275-288.

Flowerdew, M.J., Tyrrell, S., Riley, T.R., Whitehouse, M.J., Mulvaney, R., Leat, P.T., Marschall, H.R., 2012. Distinguishing East and West Antarctic sediment sources using the $\mathrm{Pb}$ isotope composition of detrital K-feldspar. Chemical Geology 292-293, 88-102.

Flowerdew, M.J., Tyrrell, S., Boger, S.D., Fitzsimons, I.C.W., Harley, S.L., Mikhalsky, E.V., Vaughan, A.P.M., 2013. Pb isotopic domains from the Indian Ocean sector of Antarctica: implications for past Antarctica-India connections. Geological Society London, Special Publications 383 (1), 59-72.

Fogwill, C.J., Bentley, M.J., Sugden, D.E., Kerr, A.R., Kubik, P.W., 2004. Cosmogenic nuclides 10Be and 26Al imply limited Antarctic Ice Sheet thickening and low erosion in the Shackleton Range for $>1$ m.y. Geology 32, 265-268.

Fretwell, P., Pritchard, H.D., Vaughan, D.G., Bamber, J.L., Barrand, N.E., Bell, R., ... \& Siegert, M. J., 2013. Bedmap2: improved ice bed, surface and thickness datasets for Antarctica. The Cryosphere, 7 (1).

Gallagher, K., Brown, R., Johnson, C., 1998. Fission track analysis and its applications to geological problems. Annual Review of Earth and Planetary Sciences 26, 519-572.

Giorgetti, G., Talarico, F.M., Sandroni, S., Zeoli, A., 2009. Provenance of Pleistocene sediments in the ANDRILL AND-1B drillcore: Clay and heavy mineral data. Global and Planetary Change 69, 94-102.

Gogineni, S., Yan, J.-B., Paden, J., Leuschen, C., Li, J., Rodriguez-Morales, F., Braaten, D., Purdon, K., Wang, Z., Liu, W., Gauch, J., 2014. Bed topography of Jakobshavn Isbrae, Greenland, and Byrd Glacier, Antarctica. Journal of Glaciology 60, 813-833.

Goldstein, S., Hemming, S.R., 2003. Long Lived isotopic tracers in oceanography, paleoceanography and ice-sheet dynamics. Treatise on Geochemistry 6, 453-489.

Golledge, N.R., Levy, R.H., McKay, R.M., Fogwill, C.J., White, D.A., Graham, A.G.C., Smith, J.A., Hillenbrand, C-D., Licht, K.J., Denton, G.H., Ackert Jr., R.P., Maas, S.M., Hall, B.L., 2013. Glaciology and geological signature of the Last Glacial Maximum Antarctic ice sheet. Quaternary Science Reviews $78,225-247$. 
Goodge, J.W., Fanning, C.M., 1999. 2.5 b.y. of punctuated Earth history as recorded in a single rock. Geology 27, 1007-1010.

Goodge, J. W., Williams, I. S., Myrow, P., 2004. Provenance of Neoproterozoic and lower Paleozoic siliciclastic rocks of the central Ross orogen, Antarctica: Detrital record of rift-, passive-, and activemargin sedimentation. Geological Society of America Bulletin, 116, 1253-1279.

Goodge, J.W., Vervoort, J.D., Fanning, C.M., Brecke, D.M., Farmer, G.L., Williams, I.W., Myrow, P.M., DePaolo, D.J., 2008. A positive test of East Antarctica-Laurentia juxtaposition within the Rodinia supercontinent. Science 321, 235-240.

Goodge, J., Fanning, M., Brecke, D., Licht, K., Palmer, E., 2010. Continuation of the Laurentian Grenville province across the Ross Sea margin of Antarctica. Journal of Geology 118, 601-619.

Grousset, F.E., Biscaye, P.E., 2005. Tracing dust sources and transport patterns using Sr, Nd, and Pb isotopes. Chemical Geology 222, 149-167.

Hall B.L., Denton, G.H., 2000. Extent and chronology of the Ross Sea ice sheet and the Wilson Piedmont Glacier along the Scott Coast at and since the last glacial maximum. Geografiska annaler (A), 82, 337363.

Haldorsen, S., 1981. Grain-size distribution of subglacial till and its relation to glacial crushing and abrasion. Boreas 10, 91-105.

Hanchar, J.M., Hoskin, P.W.O., 2003. Zircon. Reviews in Mineralogy and Geochemistry 53, 500pp.

Harley, S.L., Fitzsimons, I.C.W., Zhao, Y., 2013. Antarctica and supercontinent evolution: historical perspectives, recent advances and unresolved issues. In: Harley, S.L., Fitzsimons, I.C.W., Zhao, Y., (Eds.), Antarctica and supercontinent evolution. Geological Society of London, Special Publication 383, pp. 1-34.

Hauptvogel, D.W., Passchier, S., 2012. Early-Middle Miocene (17-14 Ma) Antarctic ice dynamics reconstructed from the heavy mineral provenance in the AND-2A drill core, Ross Sea, Antarctica. Global and Planetary Change 82-83, 38-50.

Hemming, S.R., 2004. Heinrich events: Massive late Pleistocene detritus layers of the North Atlantic and their global climate imprint. Reviews of Geophysics 42, 43pp.

Hemming, S.R., McLennan, S.M., 2001. Pb isotope compositions of modern deep sea turbidites. Earth and Planetary Science Letters 184, 489-503.

Hemming, S.R., Van De Flierdt, T., Goldstein, S.L., Franzese, A.M., Roy, M., Gastineau, G., Landrot, G., 2007. Strontium isotope tracing of terrigenous sediment dispersal in the Antarctic Circumpolar Current: implications for constraining frontal positions. Geochemistry, Geophysics, Geosystems 8 (6), doi:10.1029/2006GC001441.

Heroy, D.C., Sjunneskog, C., Anderson, J.B., 2008. Holocene climate change in the Bransfield Basin, Antarctic Peninsula: evidence from sediment and diatom analysis. Antarctic Science 20, 69-87. 
Hillenbrand, C.-D., Kuhn, G., Frederichs, T., 2009. Record of a Mid-Pleistocene depositional anomaly in West Antarctic continental margin sediments: an indicator for ice-sheet collapse? Quaternary Science Reviews 28, 1147-1159.

Hodges, K.V., Ruhl, K.W., Wobus, C.W., Pringle, M.S., 2005. ${ }^{40} \mathrm{Ar} /{ }^{39} \mathrm{Ar}$ thermochronology of detrital minerals. Reviews in Mineralogy and Geochemistry 58, 239-257.

Hollin, J.T., 1962. On the glacial history of Antarctica. Journal of Glaciology 4, 173-195.

Hooke, R.L., Cummings, D.L., Lesemann, J.E., Sharpe, D.R., 2013. Genesis of dispersal plumes in till. Canadian Journal of Earth Sciences 50, 847-855.

Ingersoll, R.V., Bullard, T.F., Ford, R.L., Grimm, J.P., Pickle, J.D., Sares, S.W., 1984. The effect of grain size in detrital modes: a test of the Gazzi-Dickinson point-counting method. Journal of Sedimentary Petrology 54, 103-116.

Jamieson, S.S.R., Sugden, D.E., Hulton, N.R.J., 2010. The evolution of the subglacial landscape of Antarctica: Earth and Planetary Science Letters 293, 1-27.

Joughin, I., Smith, B., Medley, B., 2014. Marine ice sheet collapse potentially under way for the Thwaites Glacier Basin, West Antarctica. Science 344, 735-738.

Kaplan, M., Licht, K., Winckler, G., Schaefer, J., Mathieson, C., Bader, N., 2014. Blue Ice Moraines as an Archive of Past EAIS dynamics: Mt. Achernar as a Case Study in the Central Transantarctic Mountains. Abstract PP21A-1310, 2014 Fall Meeting, AGU, San Francisco, CA.

Kanfoush, S.L., Hodell, D.A., Charles, C.D., Guilderson, T.P., Mortyn, P.G., Ninnemann, U.S., 2000. Millennial-scale instability of the Antarctic Ice Sheet during the last glaciation. Science 288, 1815-1818.

Kennett, J.P., 1977. Cenozoic evolution of Antarctic glaciation, the circum-Antarctic Ocean, and their impact on global paleoceanography. Journal of Geophysical Research 82, 3843-3860, DOI 10.1029/JC082i027.

Kramer, K.L., 2008. Provenance study of Reedy Glacier and West Antarctic ice stream tills. Indiana University M.S. thesis $60 \mathrm{pp}$.

Licht, K.J., Palmer, E.F., 2013. Erosion and transport by Byrd Glacier, Antarctica during the last glacial maximum. Quaternary Science Reviews 62, 32-48.

Licht, K.J., Lederer, J.R., Swope, R.J., 2005. Provenance of LGM glacial till (sand fraction) across the Ross Embayment, Antarctica. Quaternary Science Reviews 24, 1499-1520.

Licht, K.J., Hennessy, A.J., Welke, B.M., 2014. The U/Pb detrital zircon signature of West Antarctic ice stream tills in the Ross Embayment, with implications for LGM ice flow reconstructions. Antarctic Science 26, 687-697.

Livingstone, S.J., O’Cofaigh, C., Stokes, C.R., Hillenbrand, C.D., Vieli, A., Jamieson, S.S.R., 2012. Antarctic palaeo-ice streams. Earth-Science Reviews 111, 90-128. 
McCulloch, M.T., Wasserburg, G.J., 1978. Sm-Nd and Rb-Sr chronology of continental crust formation. Science 200, 1003-1011.

McDougall, I., Harrison, T.M., 1999. Geochronology and Thermochronology by the ${ }^{40} \mathrm{Ar} /{ }^{39} \mathrm{Ar}$ Method. Oxford University Press, Oxford, 269pp.

Moecher, D.P., Samson, S.D., 2006. Differential zircon fertility of source terranes and natural bias in the detrital zircon record: Implications for sedimentary provenance analysis. Earth and Planetary Science Letters 247, 252-266.

Monien, D., Kuhn, G., von Eynatten, H., Talarico, F.M., 2012. Geochemical provenance analysis of finegrained sediment revealing Late Miocene to recent paleo-environmental changes in the western Ross Sea. Global and Planetary Change 96-97, 41-58.

Naish, T., Powell, R., Levy, R., Wilson, G., Scherer, R., Talarico, F., Krissek, L., Niessen, F., Pompilio, M., Wilson, T., Carter, L., DeConto, R., Huybers, P., McKay, R., Pollard, D., Ross, J., Winter, D., Barrett, P., Browne, G., Cody, R., Cowan, E., Crampton, J., Dunbar, G., Dunbar, N., Florindo, F., Gebhardt, C., Graham, I., Hannah, M., Hansaraj, D., Harwood, D., Helling, D., Henrys, S., Hinnov, L., Kuhn, G., Kyle, P., Laufer, A., Maffioli, P., Magens, D., Mandernack, K., McIntosh, W., Millan, C., Morin, R., Ohneiser, C., Paulsen, T., Persico, D., Raine, I., Reed, J., Riesselman, C., Sagnotti, L., Schmitt, D., Sjunneskog, C., Strong, P., Taviani, M., Vogel, S., Wilch, T., Williams, T., 2009. Obliquity-paced Pliocene West Antarctic ice sheet oscillations. Nature 458, 322-328.

Nielsen, S.H.H., Hodell, D.A., 2007. Antarctic ice-rafted detritus (IRD) in the South Atlantic: Indicators of iceshelf dynamics or ocean surface conditions? U.S. Geological Survey and The National Academies; USGS OF-2007-1047, Short Research Paper 020; doi:10.3133/of2007-1047.srp02.

Palmer, E.F., Licht, K.J., Swope, R.J., Hemming, S.R., 2012. Nunatak moraines as a repository of what lies beneath the East Antarctic ice sheet. In: Rasbury, E.T., Hemming, S.R., Riggs, N.R., (Eds.), Mineralogical and Geochemical Approaches to Provenance. Geological Society of America Special Paper 487, 97-104, doi:10.1130/2012.2487(05).

Pankhurst, R.J., Weaver, S.D., Bradshaw, J.D., Storey, B.C., Ireland, T.R., 1998. Geochronology and geochemistry of pre-Jurassic superterranes in Marie Byrd Land, Antarctica. Journal of Geophysical Research: Solid Earth 103 (B2), 2529-2547.

Passchier, S., 2001. Provenance of the Sirius Group and related Upper Cenozoic glacial deposits from the Transantarctic Mountains, Antarctica: relation to landscape evolution and ice-sheet drainage. Sedimentary Geology 144, 263-290.

Passchier, S., 2004. Variability in geochemical provenance and weathering history of Sirius Group strata, Transantarctic Mountains: implications for Antarctic glacial history. Journal of Sedimentary Research 74, 607-619.

Passchier, S., 2011. Linkages between East Antarctic Ice Sheet extent and Southern Ocean temperatures based on a Pliocene high-resolution record of ice-rafted debris off Prydz Bay, East Antarctica.

Paleoceanography 26, PA4204, doi:10.1029/2010PA002061. 
Passchier, S., Ciarletta, D.J., Miriagos, T.E., Bijl, P.K., Bohaty, S.M., 2016. An Antarctic stratigraphic record of stepwise ice growth through the Eocene-Oligocene transition. Geological Society of America Bulletin, B31482.1, doi:10.1130/B31482.1

Petschick, R., Kuhn, G., Gingele, F.X., 1996. Clay mineral distributions in surface sediments of the South Atlantic: Origin, transport, and relation to oceanography. Marine Geology 130, 203-229.

Pierce, E.L., Williams, T., van de Flierdt, T., Hemming, S.R., Goldstein, S.L., Brachfeld, S.A, 2011. Characterizing the sediment provenance of East Antarctica's weak underbelly: the Aurora and Wilkes subglacial basins. Paleoceanography 26, doi:10.1029/2011PA002127.

Pierce, E.L., Hemming, S.R., Williams, T., van de Flierdt, T., Thomson, S.N., Reiners, P.W., Gehrels, G.E., Brachfeld, S.A., Goldstein, S.L., 2014. A comparison of detrital U-Pb, ${ }^{40} \mathrm{Ar} /{ }^{39} \mathrm{Ar}$ hornblende, ${ }^{40} \mathrm{Ar} /{ }^{39} \mathrm{Ar}$ biotite ages in marine sediments off East Antarctica: Implications for the geology of subglacial terrains and provenance studies. Earth-Science Reviews 138, 156-178.

Pollard, D., DeConto, R.M., Alley, R.B., 2015. Potential Antarctic Ice Sheet retreat driven by hydrofracturing and ice cliff failure. Earth and Planetary Science Letters 412, 112-121.

Porter, S. C., Beget, J. E., 1981. Provenance and Depositional Environments of Late Cenozoic Sediments in Permafrost Cores from Lower Taylor Valley, Antarctica. In: Mcginnis, L.D., (Ed.), Dry Valley Drilling Project. American Geophysical Union, Washington, D.C., doi: 10.1029/AR033p0351.

Pudsey, C.J., Murray, J.W., Appleby, P., Evans, J., 2006. Ice shelf history from petrographic and foraminiferal evidence, Northeast Antarctic Peninsula. Quaternary Science Reviews 25, 2357-2379.

RAISED consortium, 2014. A community-based geological reconstruction of Antarctic Ice Sheet deglaciation since the Last Glacial Maximum. Quaternary Science Reviews 100, 1-9.

Reiners, P.W., 2005. Zircon (U-Th)/He Thermochronometry. Reviews in Mineralogy and Geochemistry $58,151-176$.

Reiners, P.W., Brandon, M.T., 2006. Using thermochronology to understand orogenic erosion. Annual Reviews in Earth Planetary Science 34, 419-466.

Rignot, E., Mouginot, J., Morlighem, M., Seroussi, H., Scheuchl, B., 2014. Widespread, rapid grounding line retreat of Pine Island, Thwaites, Smith, and Kohler glaciers, West Antarctica, from 1992-2011. Geophysical Research Letters 41, 3502-3509.

Roy, M., van de Flierdt, T., Hemming, S.R., Goldstein, S.L., 2007. ${ }^{40} \mathrm{Ar} /{ }^{39} \mathrm{Ar}$ ages of hornblende grains and bulk Sm/Nd isotopes of circum-Antarctic glacio-marine sediment: Implications for sediment provenance in the southern ocean. Chemical Geology 244, 507-519.

Ruddiman, W. F., 1977. Late Quaternary deposition of ice-rafted sand in the subpolar North Atlantic (lat $40^{\circ}$ to $65^{\circ} \mathrm{N}$ ). Geological Society America Bulletin 88, 1813-1827.

Setti, M., Marinoni, L., López-Galindo, A., Aboud, A.B., 1998. TEM observations and rare earth element analysis on the clay minerals of the CRP-1 Core (Ross Sea, Antarctica). Terra Antarctica 5, 621-626. 
Shipp, S., Anderson, J., Domack, E., 1999. Late Pleistocene- Holocene retreat of the West Antarctic Ice Sheet system in the Ross Sea: Part 1- Geophysical results. Geological Society of America Bulletin 111, 1486-1516.

Siddoway, C.S., 2008. Tectonics of the West Antarctic rift system: new light on the history and dynamics of distributed intracontinental extension. In: Cooper, A.K., Raymnet, C., et al. (Eds.), Antarctica: A Keystone in a Changing World. National Academy of Sciences, 10.3133/of2007-1047.kp09.

Singer, A., 1984. A paleoclimatic interpretation of clay minerals in sediments - a review. Earth-Science Reviews 21, 251-293.

Sircombe, K.J., Stern, R.A., 2002. An investigation of artificial biasing in detrital zircon U-Pb geochronology due to magnetic separation in sample preparation. Geochimica et Cosmochimica Acta 66, 2379-2397.

Smellie, J.L., 2000. Erosional history of the Transantarctic Mountains deduced from sand grain detrital modes in CRP-2/2A, Victoria Land Basin, Antarctica. Terra Antarctica 7, 545-552.

Stetson, H.C., Upson, J.E., 1937. Bottom deposits of the Ross Sea. Journal of Sedimentary Petrology 7, 55-66.

Stewart, R.A., Mayberry, S.W., Pickerill, M.J., 1988. Composition of till in the vicinity of hte Lake Ellen Kimberlite and implications for the source of diamonds in glacial sediments of eastern Wisconsin.

Prospecting in Areas of Glaciated Terrain 8, 103-120.

Storey, B.C., 2007. Geology of the Antarctic Peninsula. In: Riffenburgh, B. (Ed.), The Encyclopedia of the Antarctic. Routledge, New York, pp. 68-73.

Stuiver, M., Denton, G.H., Hughes, T.J., Fastook, J.L., 1981. History of the marine ice sheets in West Antarctica during the last glaciation: a working hypothesis. In: Denton, G.H., Hughes, T.J. (Eds.), The Last Great Ice Sheets. Wiley-Interscience, New York, pp. 319-439.

Suttner, L.J., 1974. Sedimentary petrographic provinces: an evaluation. In: Ross, C.A. (Ed.), Paleogeographic Provinces and Provinciality. SEPM Special Publication 21, 75-84.

Suttner, L.J., Basu, A., Mack, G.H., 1981. Climate and the origin of quartz arenites. Journal of Sedimentary Petrology 51, 1235-1246.

Talarico, F.M., Sandroni, S., 2009. Provenance signatures of the Antarctic ice sheets in the Ross Embayment during the Late Miocene to Early Pliocene: The ANDRILL AND-1B core record. Global and Planetary Change 69, 103-123.

Talarico, F.M., McKay, R.M., Powell, R.D., Sandroni, S., Naish, T., 2010. Late Cenozoic oscillations of Antarctic ice sheets revealed by provenance of basement clasts and detrital grain modes in ANRILL core AND 1B. Global and Planetary Change, doi:10.1016/j.gloplacha.2009.12.002.

Talarico, F.M., Pace, D., Sandroni, S., 2011. Amphibole-bearing metamorphic clasts in ANDRILL AND2A core: A provenance tool to unravel Miocene glacial history in the Ross Embayment (western Ross Sea, Antarctica). Geosphere 7, 922-937. 
Taylor, S. R., Mclennan, S. M., McCulloch M. T., 1983. Geochemistry of loess, continental crustal composition and crustal model ages. Geochimica et Cosmochimica Acta 47, 1897- 1905.

Taylor, S.R., McLennan, S.M., 1985. The continental crust: Its composition and evolution. Blackwell Scientific, Palo Alto, CA, 312pp.

Thomson, S.N., Gehrels, G.E., Ruiz, J., Buchwaldt, R., 2012. Routine low-damage apatite U-Pb dating using laser ablation-multicollector-ICPMS. Geochemisty, Geophysics, Geosystems 13, doi:10.1029/2011GC003928.

Thomson, S.N., Reiners, P.W., Hemming, S.R., Gehrels, G.E., 2013. The contribution of glacial erosion to shaping the hidden landscape of East Antarctica. Nature Geoscience 6 (3), 203-207.

Thorleifson, L.H., Kristjansson, F.J., 1993. Quaternary geology and drift prospecting, BeardmoreGeraldton area, Ontario. Geological Survey of Canada Memoir 435, 146p.

Tingey, R.J., 1991. The regional geology of Archaean and Proterozoic rocks in Antarctica. In: Tingey, R.J., (Ed.), The geology of Antarctica. Oxford Monographs on Geology and Geophysics 17, Clarenden Press, 1-73.

Tochilin, C.J., Reiners, P.W., Thomson, S.N., Gehrels, G.E., Hemming, S.R., Pierce, E.L., 2012. Erosional history of the Prydz Bay sector of East Antarctica from detrital apatite and zircon geo- and thermochronology multidating. Geochemisty Geophysics Geosystems 13, doi:10.1029/2012GC004364

Troll, G., Matthies, D., Hofstetter, A., Skeries, W., 1992. Recent and subrecent sediments of the northwestern Weddell Sea and the Bransfield Strait, Antarctica. Polarforschung 62, 129-144.

Tulaczyk, S., Kamb, B., Scherer, R.P., Engelhardt, H.F., 1998. Sedimentary processes at the base of a West Antarctic ice stream: constraints from textural and compositional properties of subglacial sediment. Journal of Sedimentary Research 68, 487-496.

van de Flierdt, T., Hemming, S.R., Goldstein, S.L., Abouchami, W., 2006. Radiogenic isotope fingerprint of Wilkes Land-Adélie Coast Bottom Water in the circum Antarctic Ocean. Geophysical Research Letters 33, doi:10.1029/2006GL026020.

van de Flierdt, T., Goldstein, S.L., Hemming, S.R., Roy, M., Frank, M., Halliday, A.N., 2007. Global neodynmium-hafnium isotope systematics - revisited. Earth and Planetary Science Letters 259, 432-441.

van de Flierdt, T., Hemming, S.R., Goldstein, S.L., Gehrels, G.E., Cox, S.E., 2008. Evidence against a young volcanic origin of the Gamburtsev Subglacial Mountains, Antarctica. Geophysical research Letters 35, doi:10.1029/2008GL035564.

Wadham, J.L., Tranter, M., Skidmore, M., Hodson, A.J., Priscu, J., Lyons, W.B., Sharp, M., Wynn, P., Jackson M., 2010. Biogeochemical weathering under ice: Size matters. Global Biogeochemical Cycles 24, doi:10.1029/2009GB003688. 
Weber, M.E., Clark, P. U., Kuhn, G., Timmermann, A., Sprenk, D., Gladstone, R., Zhang, X., Lohmann, G., Menviel, L., Chikamoto, M.O., Friedrich, T., Ohlwein, C., 2014. Millennial-scale variability in Antarctic ice-sheet discharge during the last deglaciation. Nature 510, 134-138, doi:10.1038/nature13397.

Welke, B., Licht K., Hennessy, A., Hemming, S., Pierce-Davis, E., Kassab, C., 2016. Applications of detrital geochronology and thermochronology from glacial deposits to the Paleozoic and Mesozoic thermal history of the Ross Embayment, Antarctica. Geochemistry, Geophysics, Geosystems, doi: $10.1002 / 2015 \mathrm{GC} 005941$.

Williams, T., van de Flierdt, T., Hemming, S.R., Chung, E., Roy, M., Goldstein, S.L., 2010. Evidence for iceberg armadas from East Antarctica in the Southern Ocean during the late Miocene and early Pliocene. Earth and Planetary Science Letters 290, 351-361.

Wright, A.P., Le Brocq, A.M., Cornford, S.L., Bingham, R.G., Corr, H.F.J., Ferraccioli, F., Jordon, T.A., Payne, A.J., Rippin, D.M., Ross, N., Siegert, M.J., 2014. Sensitivity of the Weddell Sea sector ice streams to sub-shelf melting and surface accumulation. The Cryosphere 8, 2119-2134.

Yoon, H.I., Han, M.W., Park, B.K., Han, S.J., Oh, J.K., 1992. Distribution, provenance and dispersal pattern of clay minerals in surface sediment, Bransfield Strait, Antarctica. Geo-Marine Letters 12, 223 227.

Zachos, J.C., Breza, J.R., Wise, S.W., 1992. Early Oligocene ice-sheet expansion on Antarctica: stable isotope and sedimentological evidence from Kerguelen Plateau, southern Indian Ocean. Geology 20, 569573.

Zattin, M., Talarico, F.M., Sandroni, S., 2010. Integrated provenance and detrital thermochronology studies in the ANDRILL AND-2A drill core: Late Oligocene-Early Miocene exhumation of the Transantarctic Mountains (Southern Victoria Land, Antarctica). Terra Nova 22, 361-368.

Zattin, M., Andreucci, B., Thompson, S.N., Reiners, P.W., Talarico, F.M., 2012. New constraints on the provenance of the ANDRILL AND-2A succession (western Ross Sea, Antarctica) from apatite triple dating. Geochemistry, Geophysics, Geosystems 13, Q10016, doi:10.1029/2012GC004357.

Zattin, M., Pace, D., Andreucci, B., Rossetti, F., Talarico, F.M., 2014. Cenozoic erosion of the Transantarctic Mountains: A source-to-sink thermochronological study. Tectonophysics 630, 158-165. 


\section{Figure Captions}

Figure 1. (A) Locations named in text shown on the BEDMAP 2 subglacial topography from Fretwell et al. (2012) with a semi-transparent overlay of the Landsat Image Mosaic created with GeoMapApp. Red lines show ice divides, black dashed lines are ice streams, blue arrow show generalized surface currents. $\mathrm{AL}=$ Adélie Land, $\mathrm{BG}=$ Byrd Glacier, $\mathrm{DV}=$ Dry Valleys, $\mathrm{EM}=$ Ellsworth Mountains, $\mathrm{GVL}=$ George $\mathrm{V}$ Land, MA=Mt. Achernar and Law Glacier, NG=Nimrod Glacier, NVL= north Victoria Land, R$\mathrm{F}=$ Ronne-Filchner, and $\mathrm{RG}=$ Reedy Glacier, $\mathrm{SCIS}=$ Siple Coast ice streams, yellow dot marks SkeltonMulock Glaciers. (B) Model reconstruction of Antarctic ice flow lines for the Last Glacial Maximum (Golledge et al., 2013) compared to modern grounded ice extent shown on base image (gray shading).

Figure 2. Schematic diagram showing provenance products (sand petrography and detrital zircon geochronology) from ice flow across simple hypothetical geologic terranes. In this instance, the sediment comprising the sandstone is assumed to be derived from erosion of the two granites. Note that its depositional age is different from the detrital zircon ages. Products are listed in relative order of abundance. Flowline A crosses two different granites that may not be apparent from petrographic analysis of till, but would be from zircon geochronology (or other radiogenic isotopic systems) of the same samples. Till transported along flowline B may have zircon populations similar to till along flowline A, but have somewhat different petrography. Flowline $\mathrm{C}$ petrography may be similar to flowline $\mathrm{B}$, depending on comminution rate of limestone rock fragments, but its proximity to the older granite would likely yield a higher proportion of 1000 Ma zircons. The origin of the $1000 \mathrm{Ma}$ zircons might be ascribed only to the sandstone if the older granite was not exposed.

Figure 3. Geologic map of Antarctica overlain on BEDMAP topography Fretwell et al. (2012) where lighter grayscale is higher elevation. White dashed line shows the approximate division between West (left) and East (right) Antarctica, which parallels the Transantarctic Mountains. Red lines are ice divides (pers. comm., L. Stearns). Data for bedrock geology from Gondwana Map project IGCP-628 (pers. comm., Renata Schmitt, U. Federal do Rio de Janeiro).

Figure 4. (A) Schematic diagram showing influence of bed roughness on glacial erosion. Rock-rock contacts cause abrasion and crushing which typically produce sand-clay sized sediment whereas larger size fractions are produced by plucking (Boulton, 1978; Haldorsen, 1981). These processes are observed at a variety of scales. Entrained debris may move along the ice-bed contact or as englacial debris bands. Base image - Pearson Prentice Hall, Inc., 2005. (B) Longitudinal cross section along ice flow showing sediment entrainment and dispersal by basal freeze on (modified from Hooke et al., 2013). Darker shading shows higher debris concentrations. The englacial plume collapses to a deposit $<10 \mathrm{~m}$ thick. (C) Generalized variation in debris transport distance with changes in bed and ice properties.

Figure 5. (A) Erosion rates are spatially variable and so influence provenance signal offshore (from Jamieson et al., 2010). (B) Sediment flux is also spatially variable and mirrors erosion rates (from Golledge et al., 2013). The images highlight how glacial processes influence the provenance signal.

Figure 6. Common rock type contributions to the sand-size fraction of glacigenic sediments (indicated by filled boxes). The illustration highlights natural biases in provenance data that are linked to lithologic variations. For instance a study of detrital zircons would miss or underestimate carbonate and mafic rock contributions. Most rocks will be represented in petrographic studies (minus weakly indurated mudstone), however the dominant product of many rocks is quartz making its origin ambiguous. Although the detrital grains may occur in a wide range of size fractions, a small size range is typically selected for analysis (i.e., 63-250 $\mu \mathrm{m}$ ) causing them to be missed from coarser grained rocks (coarse sandstone). 
Figure 7. Closure temperatures for common geo- and thermochronometers. As a mineral cools and passes through its closure temperature, its time clock begins. A single mineral grain, like zircon, may provide both a crystallization temperature from $\mathrm{U} / \mathrm{Pb}$, as well as a shallow crustal cooling temperature $(\mathrm{He})$. In glacigenic sediments, analyzing a suite of chronometers can provide information about the thermal history of the crust that was eroded to produce the sediments (Reiners and Brandon, 2006).

Figure 8. Covariation of $\varepsilon \mathrm{Nd}$ and ${ }^{87} \mathrm{Sr} /{ }^{86} \mathrm{Sr}$ of terrigenous sediments from marine core tops around Antarctica. For reference, data from modern river suspended sediments (Goldstein and Jacobsen, 1988) and modern deep sea turbidites (McLennan et al., 1990) are shown as black diamonds. From Hemming et al., 2007.

Figure 9. (A) Debris bands emerging from blue ice at the margin of the Mt. Achernar moraine along Law Glacier in the Transantarctic Mountains (Fig. 1) and (B) Mt. Achernar moraine color bands coincident with distinct lithological changes. These changes are not evident in U-Pb zircon data because the dark red Ferrar dolerite is zircon deficient. From Bader et al., in press.

Figure 10. Detrital zircon and pebble lithologic data from 4 regions in a large moraine sequence near Mt. Achernar (Fig. 9). Increasing Zone numbers reflect increasing distance (and age) from the Law Glacier. Detrital zircons show little variability in age populations between zones whereas pebble lithology shows a major change in zone 3. Data from Bader et al., in press.

Figure 11. Summary of detrital zircon age peaks (orange boxes, ages in $\mathrm{Ma}$ ) and $\varepsilon \mathrm{Nd}(0)$ values (blue boxes) from till samples collected along the Byrd Glacier (green dots) and from central Ross Sea tills. White arrow shows ice flow direction. Shading shows bedrock geology: red is Granite Harbor Intrusives, yellow is Byrd Group and blue is Beacon/Ferrar Supergroups. LW = Lonewolf Nunataks, AB = All Blacks Nunatak, $\mathrm{MT}=\mathrm{Mt}$. Tuatara, $\mathrm{BN}=$ Bates Nunatak, $\mathrm{BR}=$ Brittania Ridge, $\mathrm{CJ}=$ Crazy Jim moraine, $\mathrm{HB}=$ Horney Bluff. Data from Farmer et al., 2006; Licht and Palmer, 2013 and Farmer and Licht, 2016.

Figure 12. Photograph of clasts from a moraine at Lonewolf Nunataks (see Fig. 11), showing examples of striated and faceted surfaces in a variety of rock types. From Palmer et al., 2012.

Figure 13. LGM ice flow reconstruction (blue lines) based on U-Pb ages from detrital zircons. Orange circles highlight the samples that contain zircons 100-110 Ma from Bindschadler (BIS) and Kamb Ice Streams (KIS). This Cretaceous zircon age population is an important West Antarctic signature. Base image is topography/bathymetry from GeoMapApp. From Licht et al., 2014.

Figure 14. Lithostratigraphy and granule- to cobble-size clast compositions of the uppermost $400 \mathrm{~m}$ of AND-1B core near Ross Island (see Fig. 1). Green-colored intervals are diamicts, yellow represents diatomites, orange is volcanic sandstone. Modified from Talarico et al., 2010.

Figure 15. Histograms (20 Myr bins) and probability plots of detrital U-Pb zircon, ${ }^{40} \mathrm{Ar} /{ }^{39} \mathrm{Ar}$ hornblende and ${ }^{40} \mathrm{Ar} /{ }^{39} \mathrm{Ar}$ biotite ages by geographic sector compared to a histogram (20 Myr bin) and probability plot of on-land ages taken from the compilation of Veevers (2012) and Veevers and Saeed (2011). The color scale corresponds to $100 \mathrm{Myr}$ increments of time. (A) DML — Dronning Maud Land, (B) PB - Prydz Bay, (C) WL - Wilkes Land and (D) AL /GVL /NVL - Adélie Land, George V Land and north Victoria Land (See Fig. 1 for locations). From Pierce et al., 2014. 
Figure 16. Maps of East Antarctica with pie charts showing the distribution of thermochronologic ages by site location and mineral type, the down-core ODP Site 1165 record of IRD, and known onshore ages. The color scale used here is the same as Fig. 15, and corresponds to $100 \mathrm{Myr}$ increments of time. (A) Pie charts displaying U-Pb zircon results, (B) Pie charts displaying ${ }^{40} \mathrm{Ar} /{ }^{39} \mathrm{Ar}$ hornblende results, (C) Pie charts displaying ${ }^{40} \mathrm{Ar} /{ }^{39} \mathrm{Ar}$ biotite results. GC - Grunehogna Craton, $\mathrm{G}$ - Gjelsvifjella, H - Haag Nunatak, HU - H.U. Sverdrupfjella, K — Kirwanveggan. From Pierce et al., 2014.

Figure 17. Argon age histograms for: (A) the samples from the IRD-rich layers at Site 1165 (see Fig. 1) grouped by provenance sector; (B) three provisional source sectors based on core-top ${ }^{40} \mathrm{Ar} /{ }^{39} \mathrm{Ar}$ data (Roy et al., 2007). All Site 1165 samples show ${ }^{40} \mathrm{Ar} /{ }^{39} \mathrm{Ar}$ ages of 500-600 Ma derived from the Prydz Bay sector; the 4.8 Ma sample shows a significant contribution of IRD from Adélie Land; and the 3.5 and 7.0 Ma samples have a significant contribution of IRD from Wilkes Land. From Williams et al., 2010.

Figure 18. Histogram illustrating Wilkes Land (see Fig. 1) data-model comparison for the relative abundance of hornblende grains (light grey boxes) and modeled iceberg melt (dark grey boxes) at four sites from the Prydz Bay region during the Holocene. This comparison illustrates the excellent agreement between the observed amount of Wilkes Land IRD relative to Prydz Bay IRD during the Holocene and the modeled preindustrial amount of Wilkes Land-derived iceberg melt relative to Prydz Bay-derived iceberg melt. From Cook et al., 2014. 

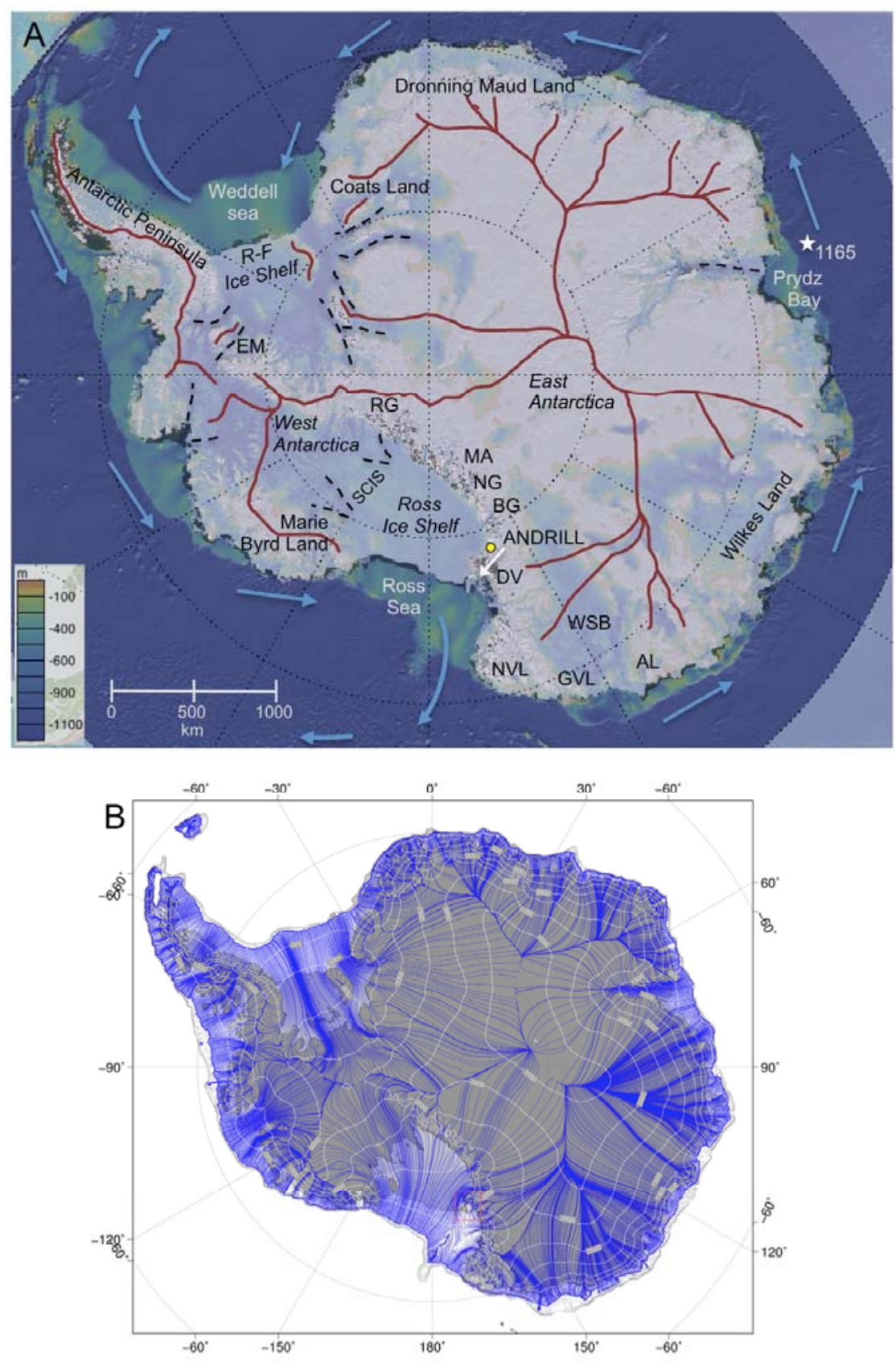

Figure 1. 


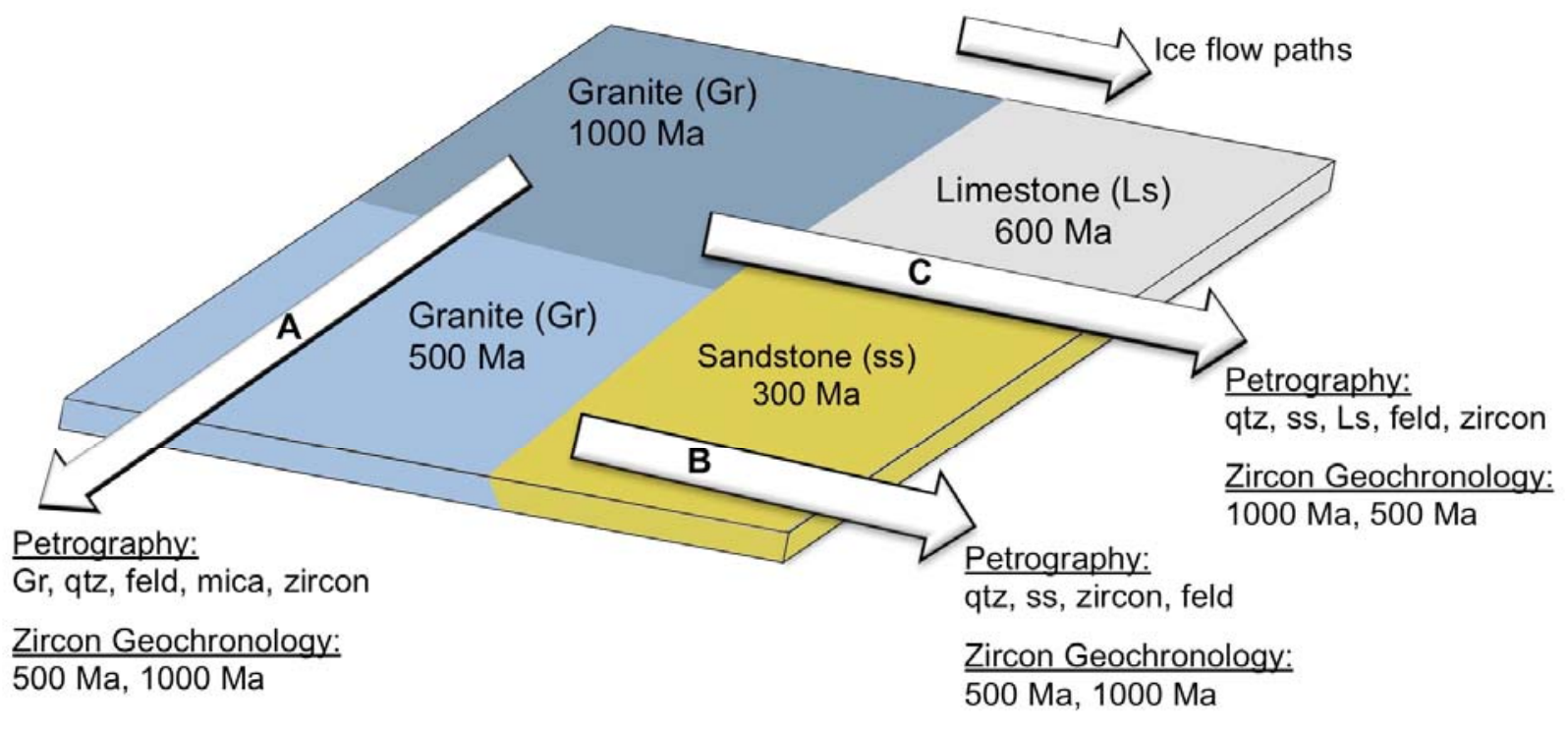

Figure 2. 


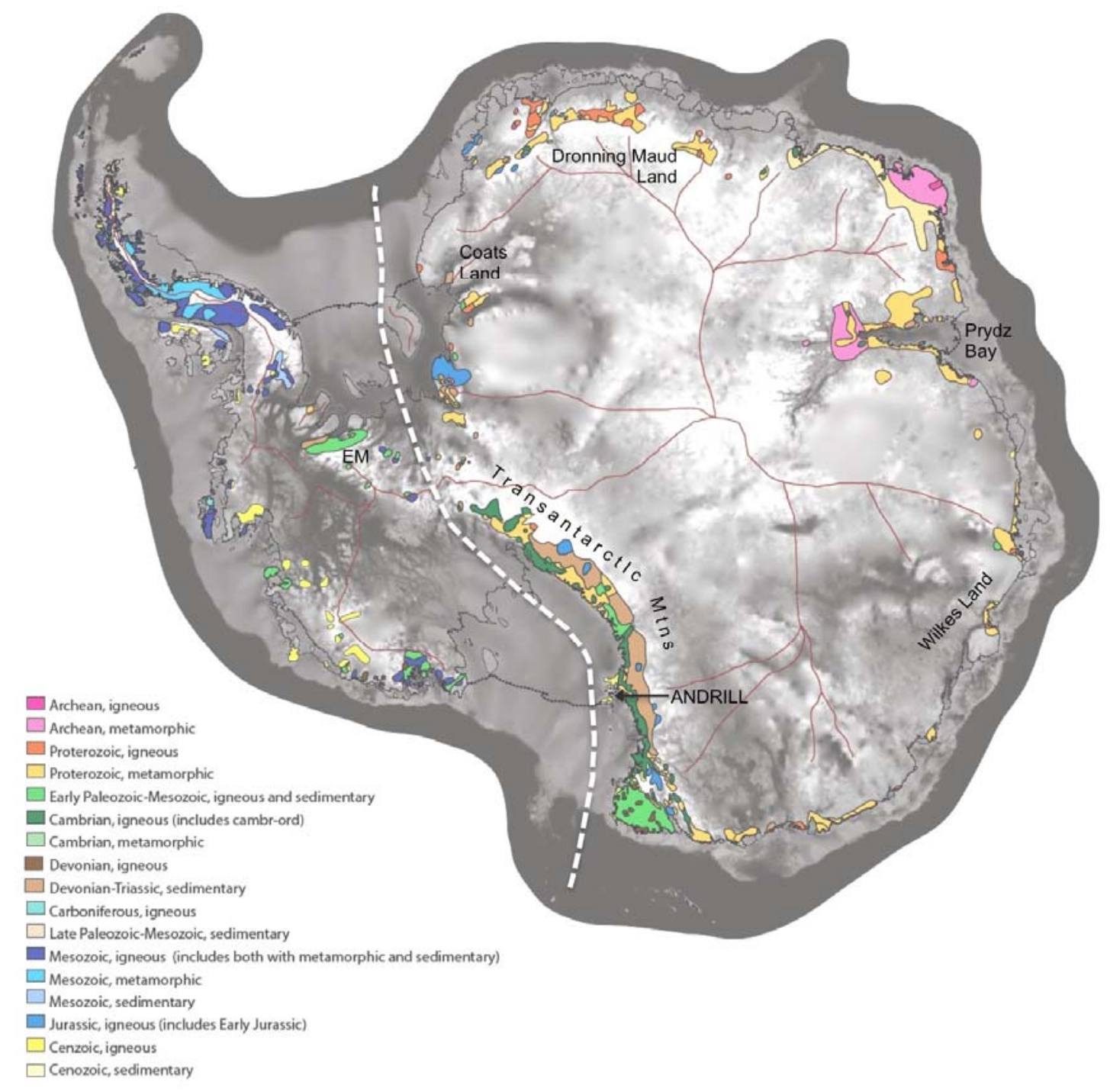

Figure 3. 

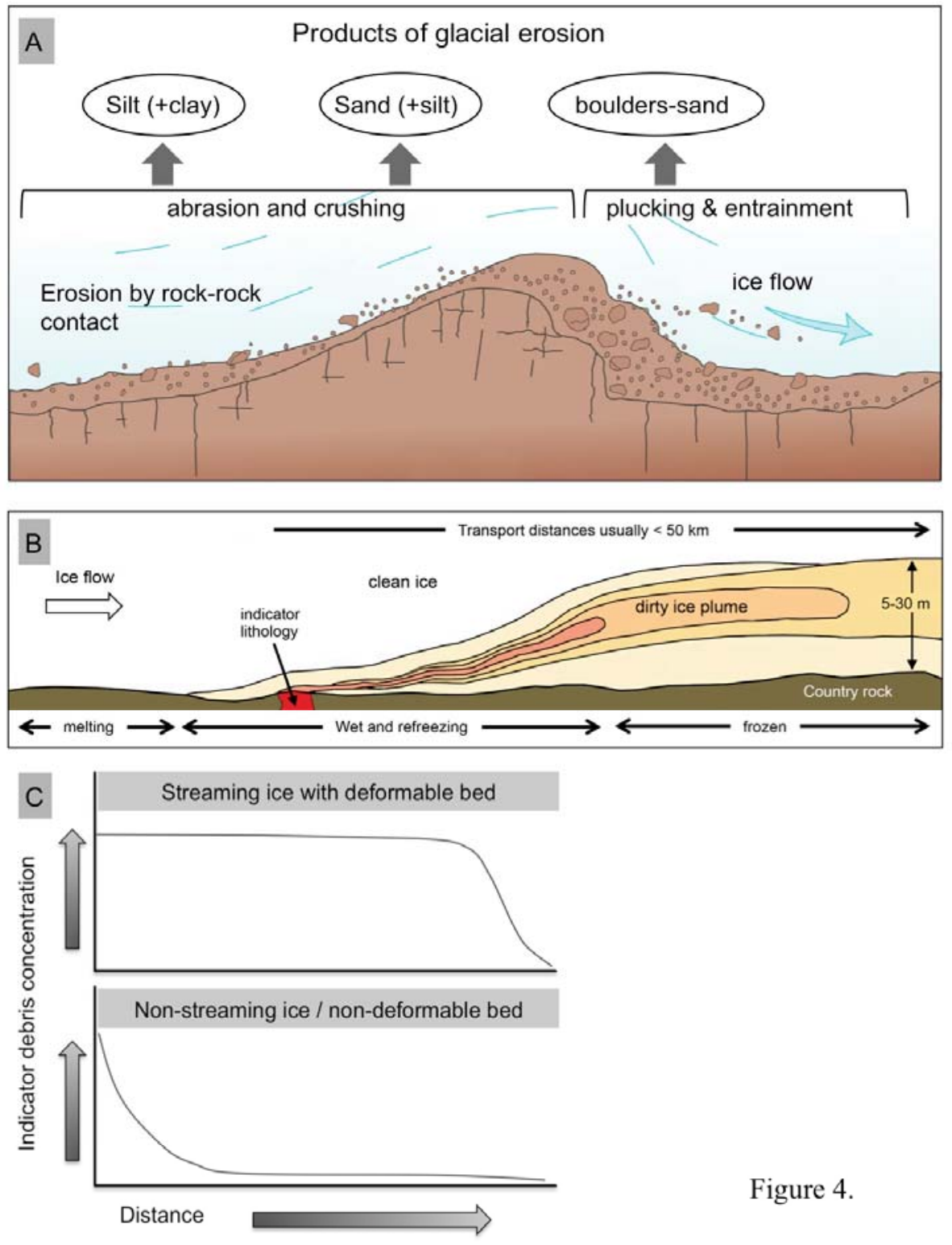

Figure 4. 

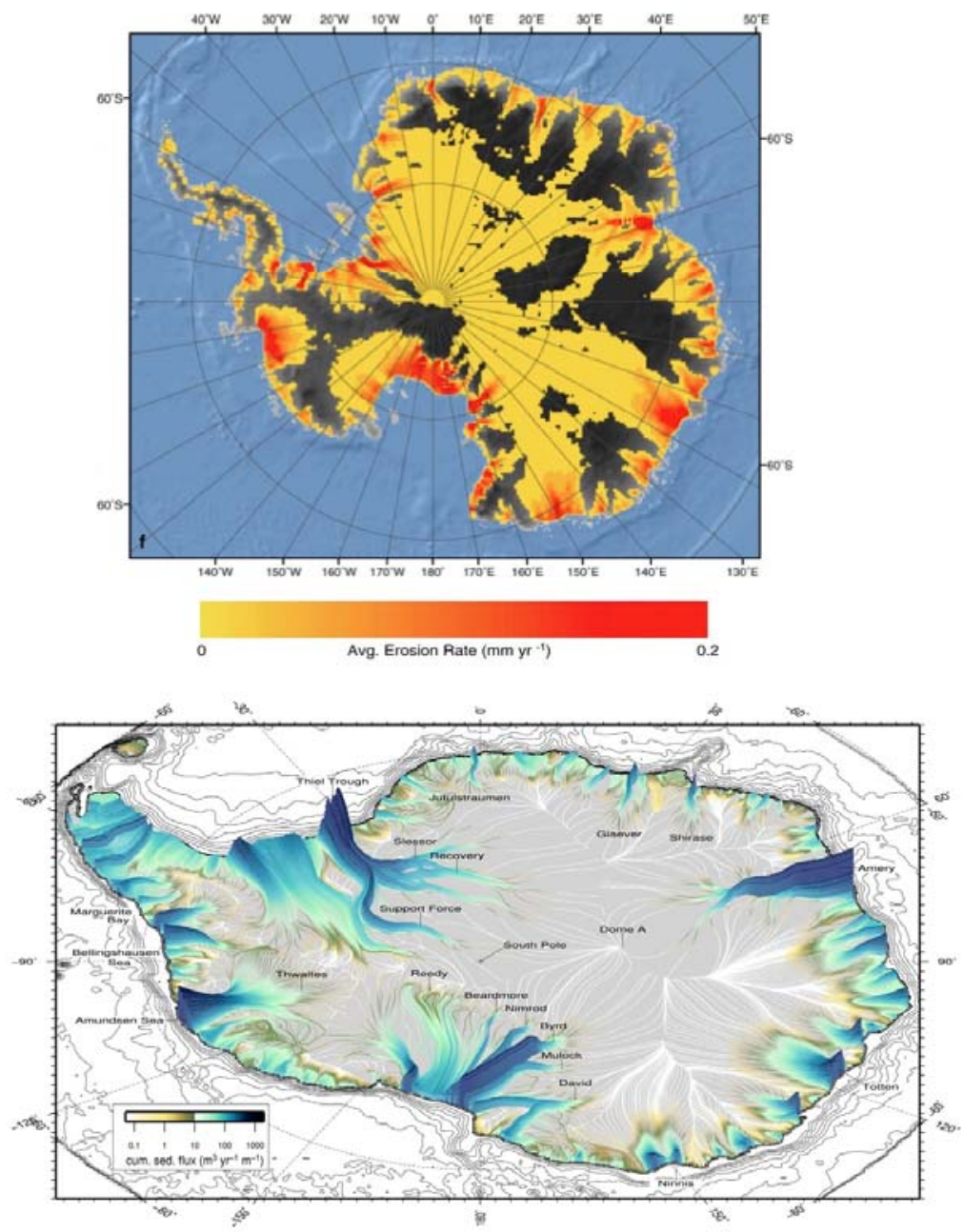

Figure 5. 


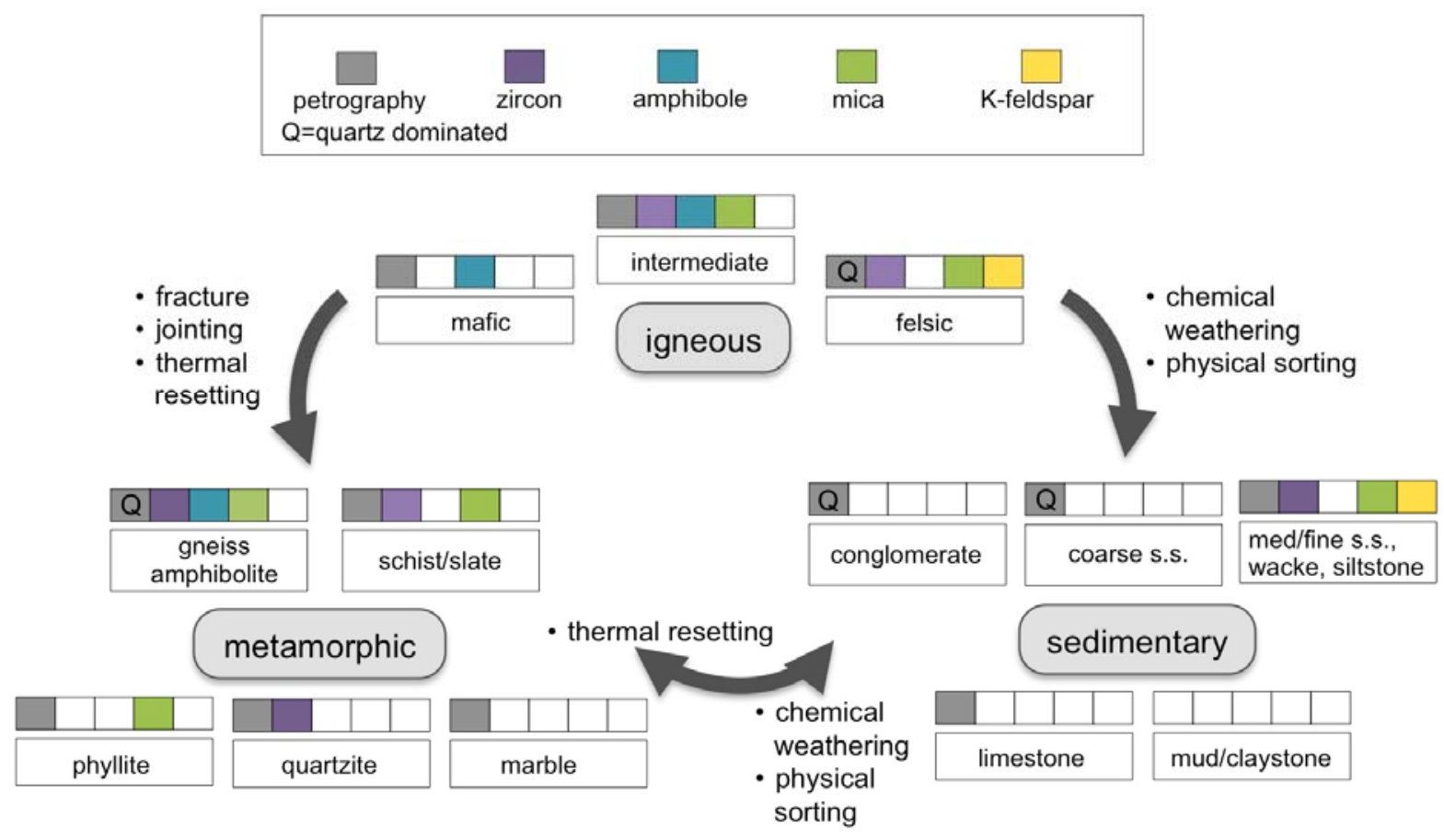

Figure 6. 


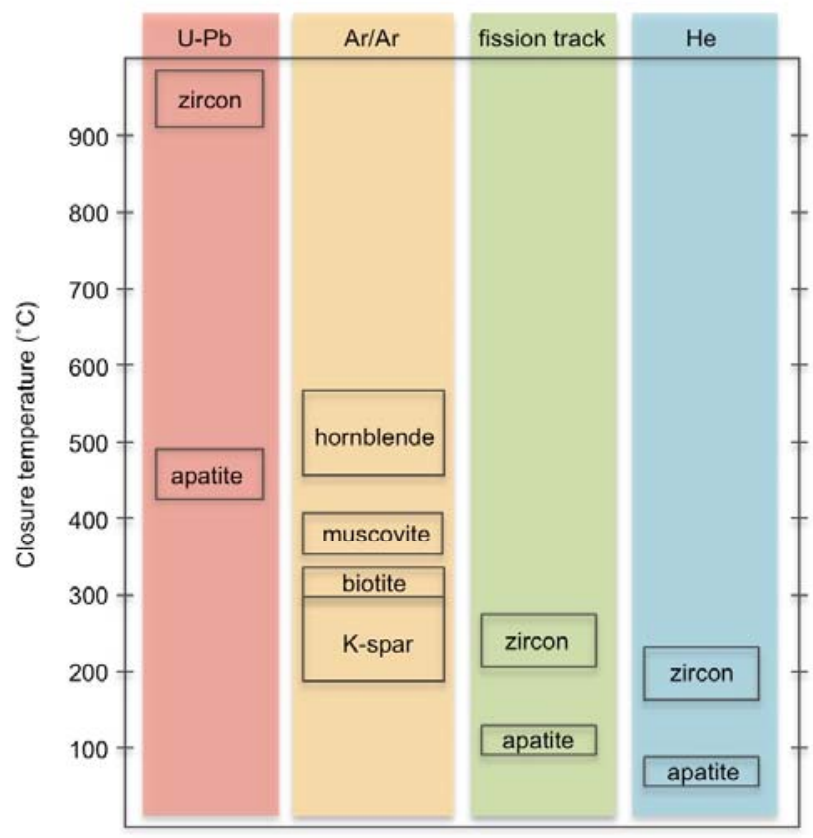

Figure 7.

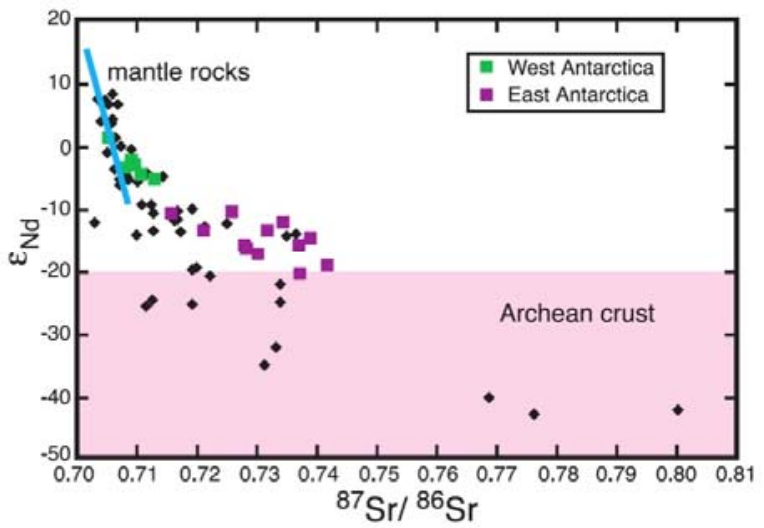

Figure 8 . 

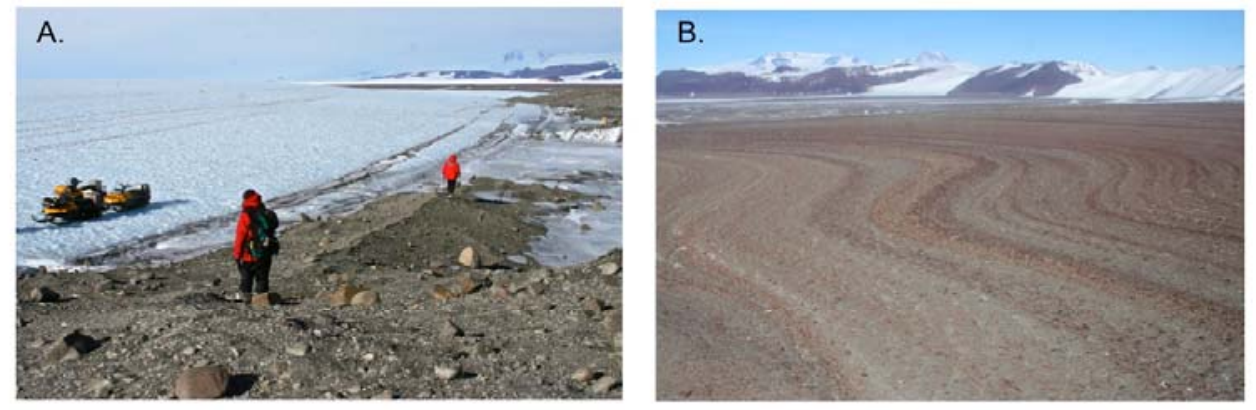

Figure 9.

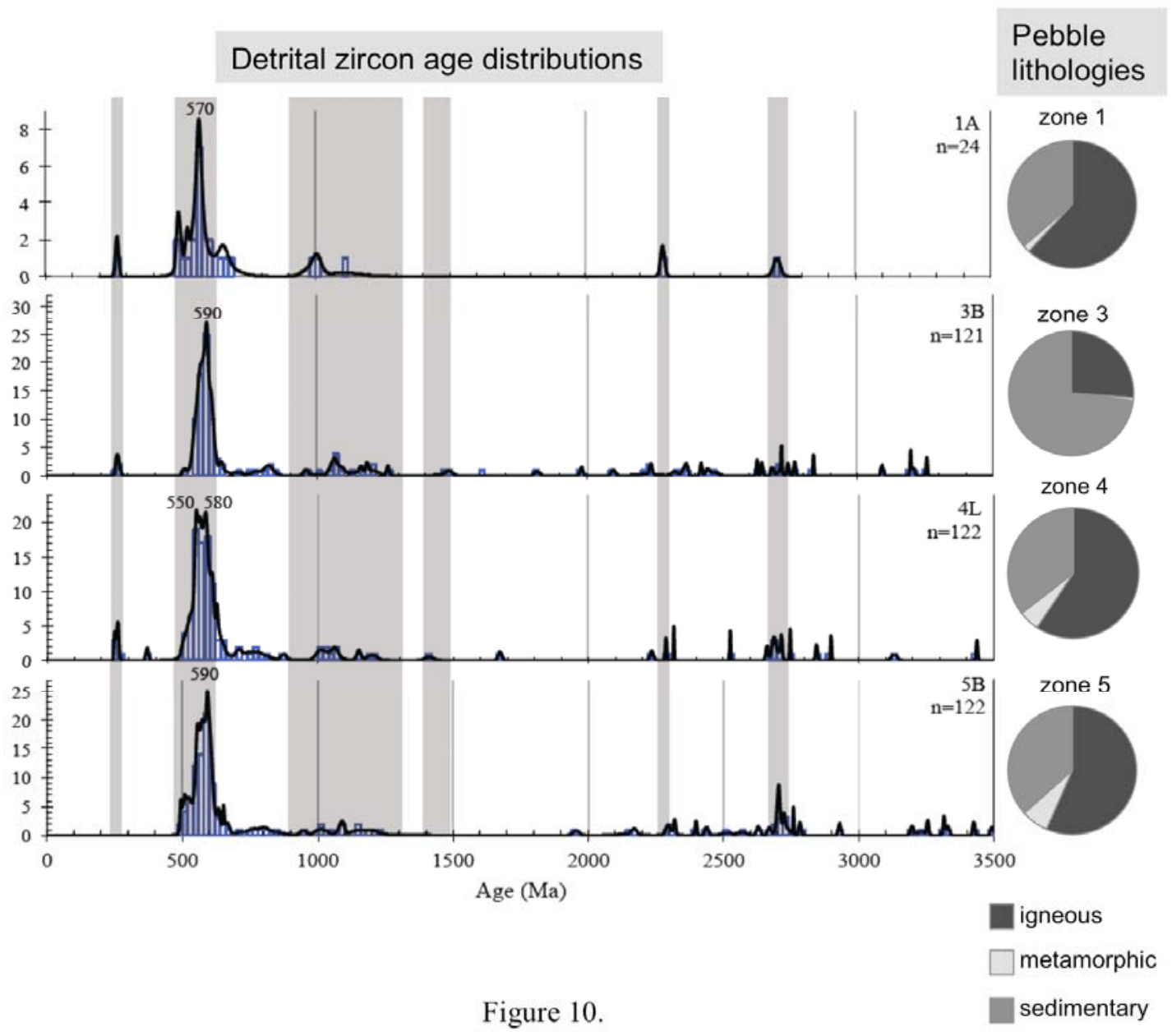




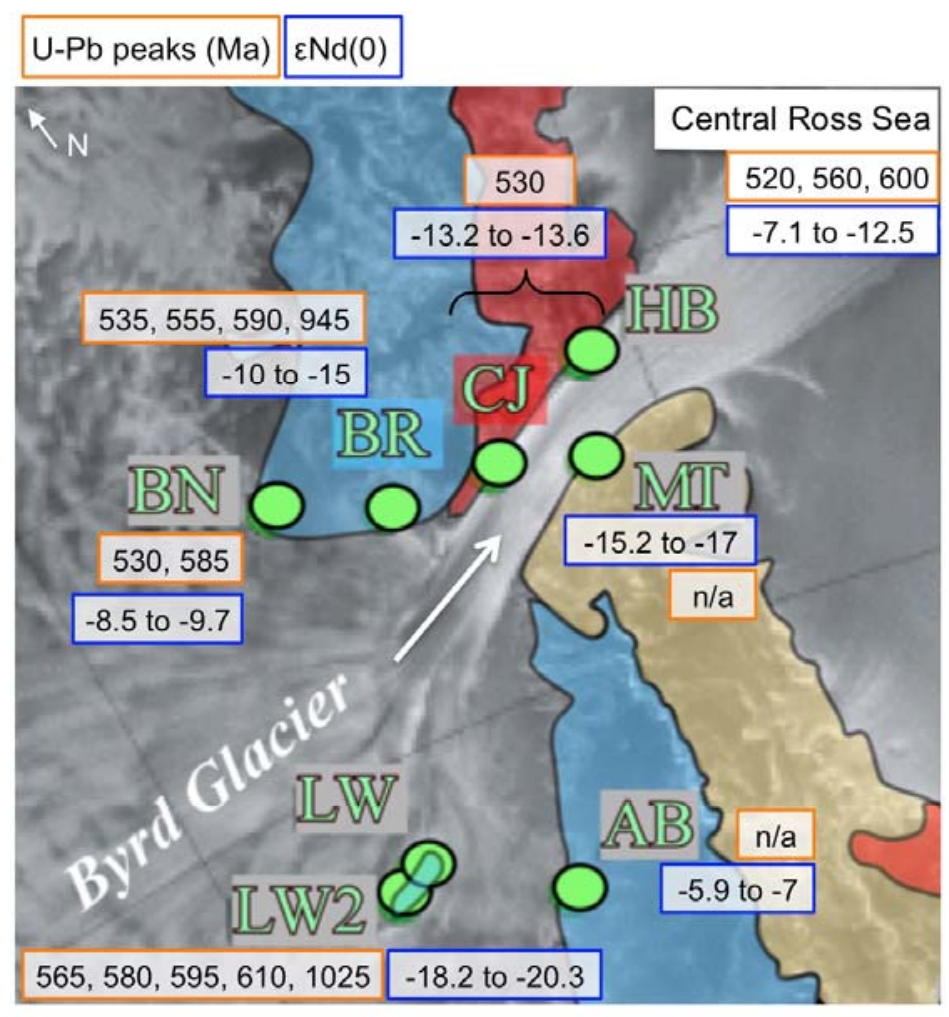

Figure 11.

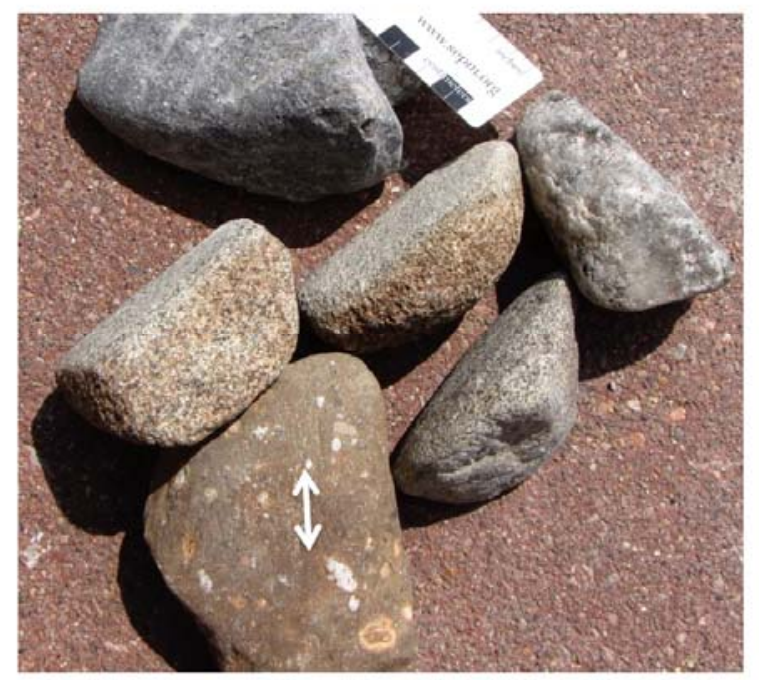

Figure 12. 


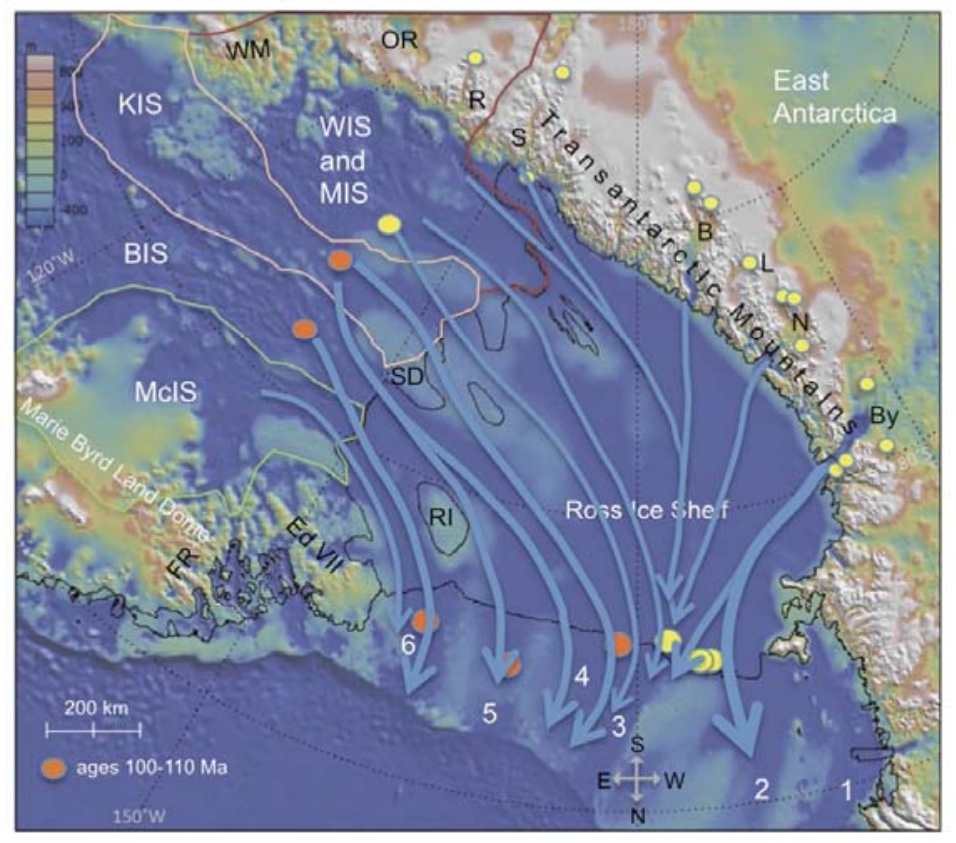

Figure 13. 


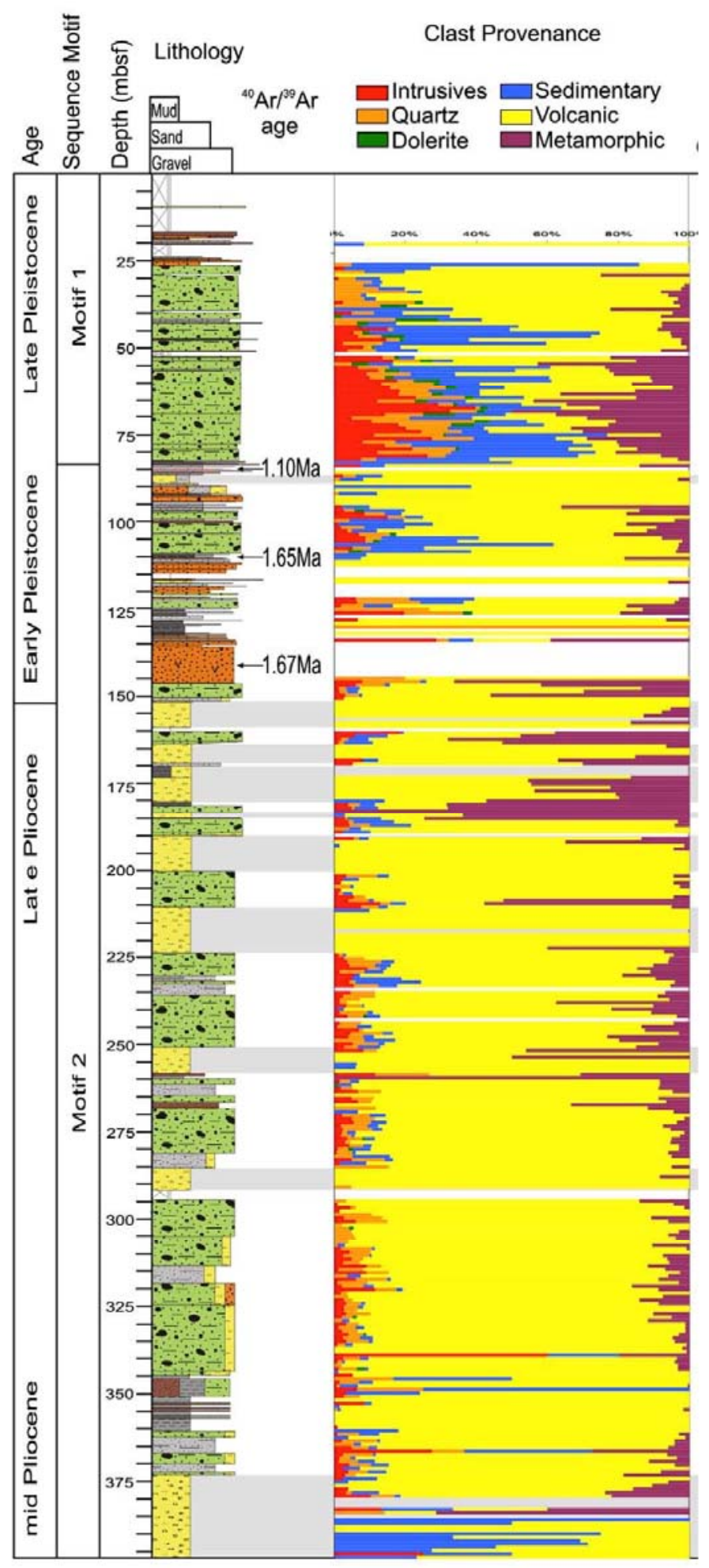

Figure 14. 

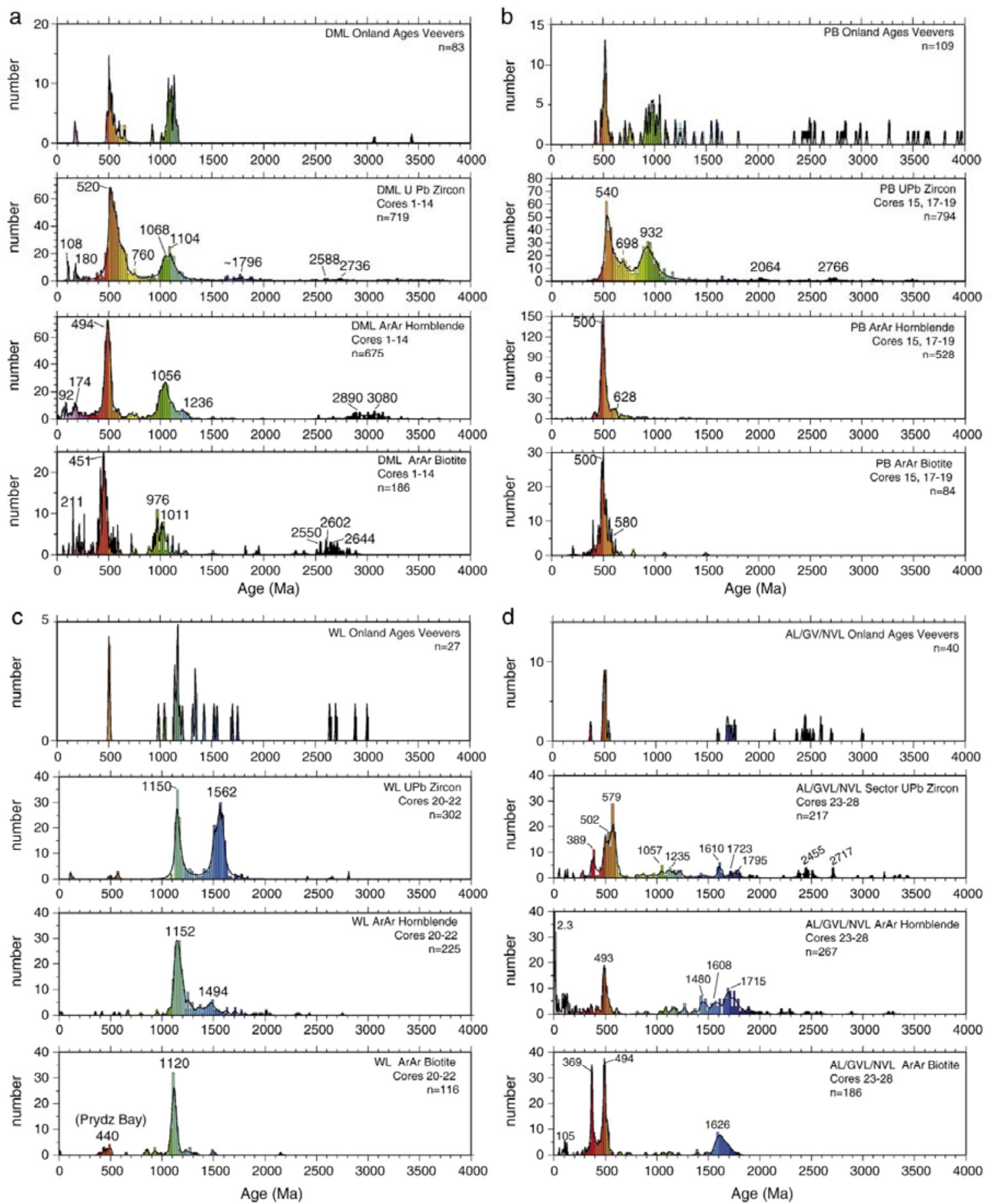

Figure 15. 

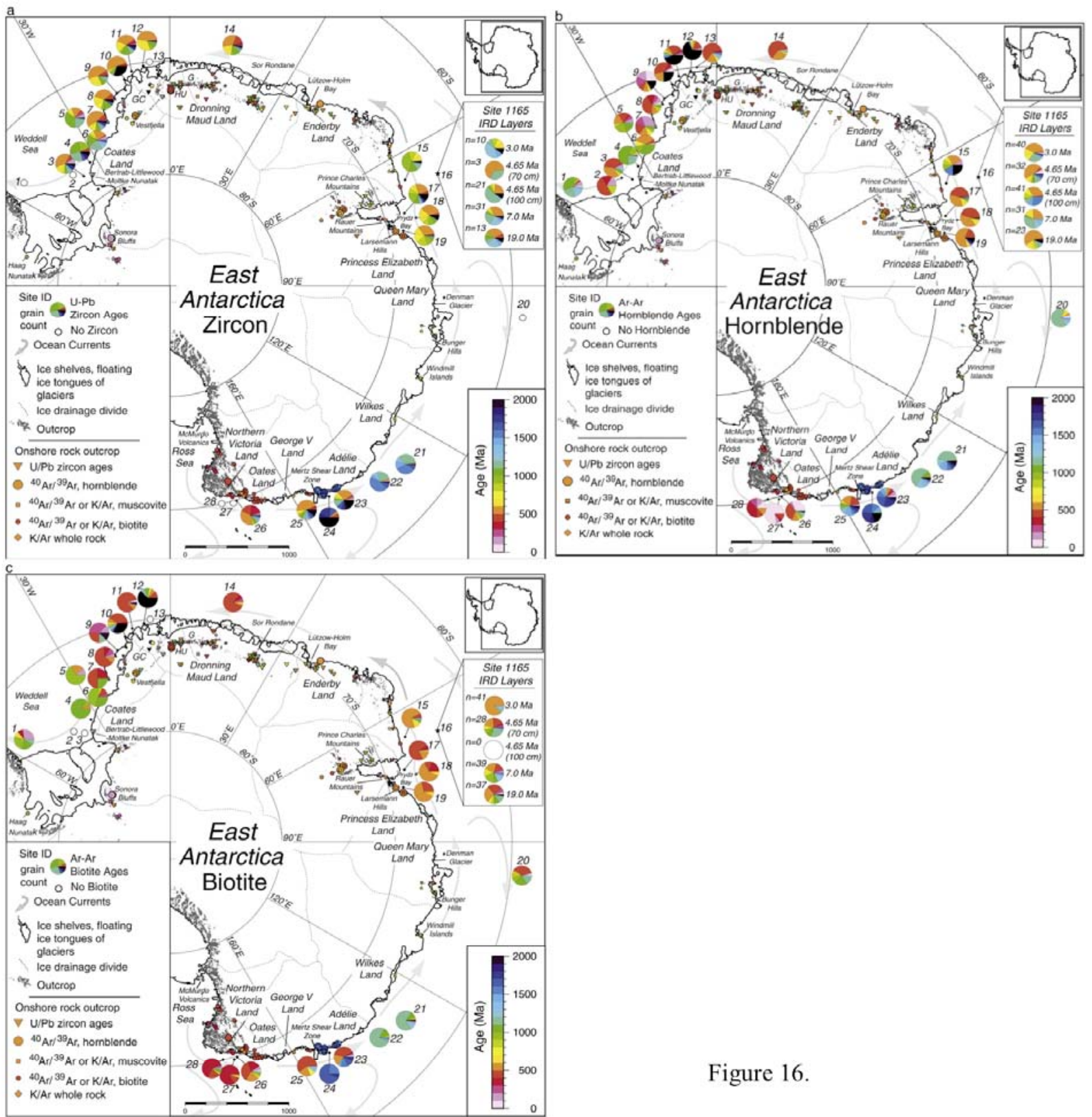

Figure 16. 


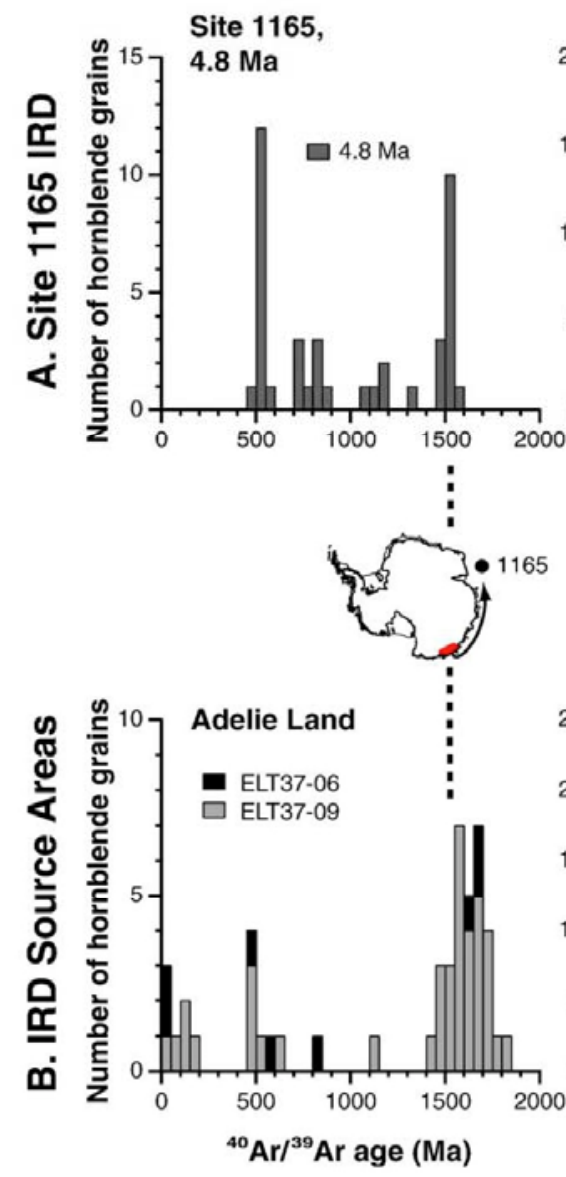

Site 1165 ,

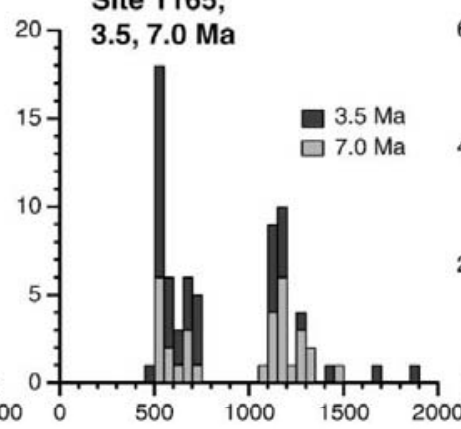

Site 1165,
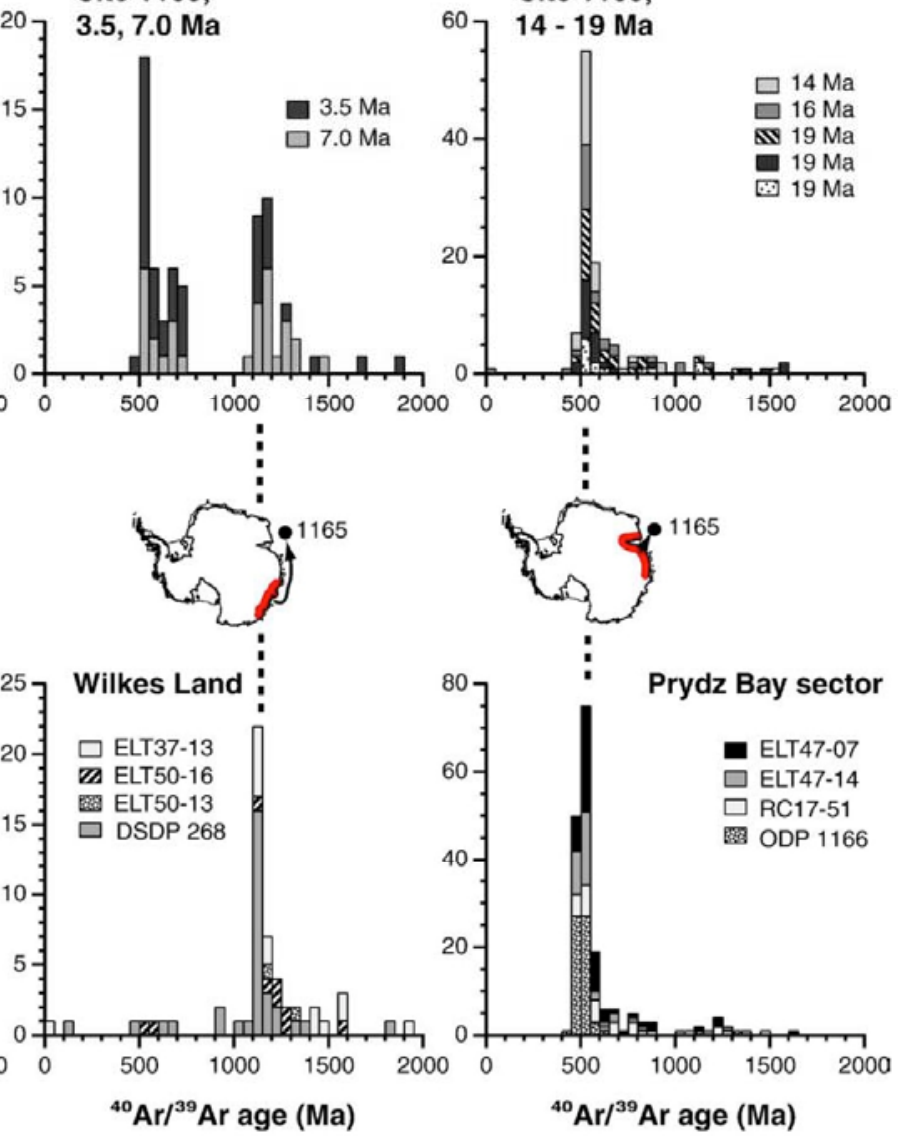

Figure 17.

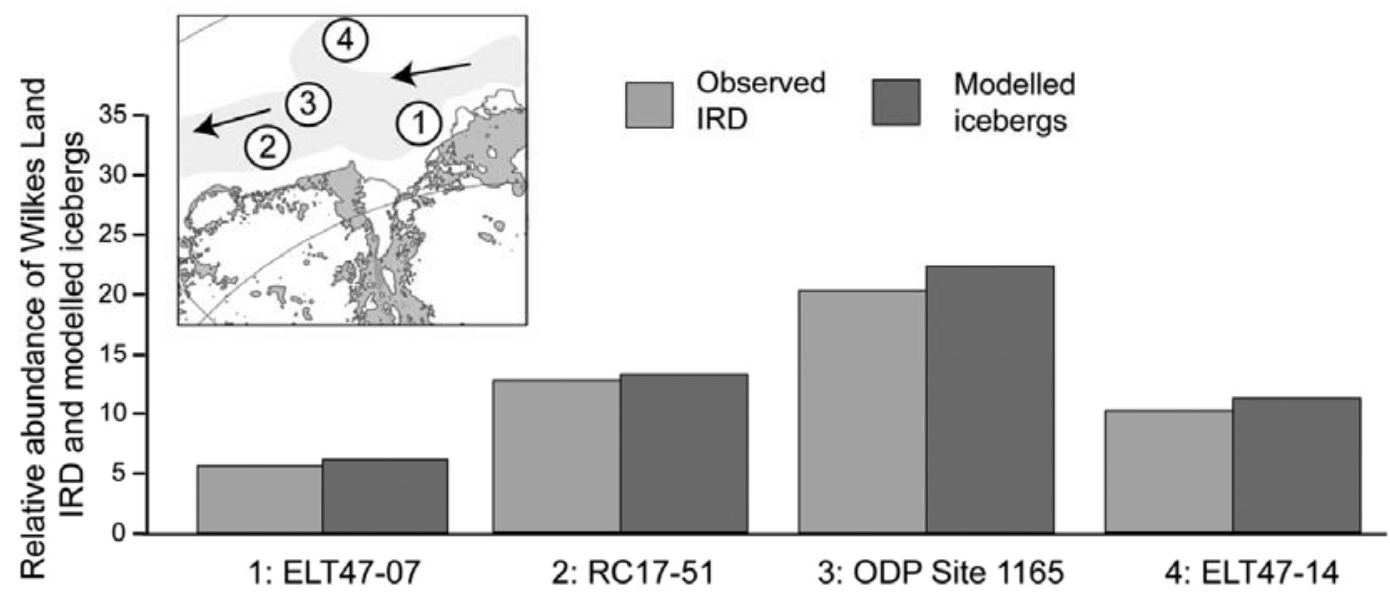

Figure 18. 